\title{
Selective activation and proliferation of a quiescent stem cell population in the neuroepithelial body microenvironment
}

\author{
Line Verckist, Isabel Pintelon, Jean-Pierre Timmermans, Inge Brouns and Dirk Adriaensen*
}

\begin{abstract}
Background: The microenvironment (ME) of neuroepithelial bodies (NEBs) harbors densely innervated groups of pulmonary neuroendocrine cells that are covered by Clara-like cells (CLCS) and is believed to be important during development and for adult airway epithelial repair after severe injury. Yet, little is known about its potential stem cell characteristics in healthy postnatal lungs.

Methods: Transient mild lung inflammation was induced in mice via a single low-dose intratracheal instillation of lipopolysaccharide (LPS). Bronchoalveolar lavage fluid (BALF), collected $16 \mathrm{~h}$ after LPS instillation, was used to challenge the NEB ME in ex vivo lung slices of control mice. Proliferating cells in the NEB ME were identified and quantified following simultaneous LPS instillation and BrdU injection.

Results: The applied LPS protocol induced very mild and transient lung injury. Challenge of lung slices with BALF of LPS-treated mice resulted in selective $\mathrm{Ca}^{2+}$-mediated activation of CLCs in the NEB ME of control mice. Forty-eight hours after LPS challenge, a remarkably selective and significant increase in the number of divided (BrdU-labeled) cells surrounding NEBs was observed in lung sections of LPS-challenged mice. Proliferating cells were identified as CLCs.

Conclusions: A highly reproducible and minimally invasive lung inflammation model was validated for inducing selective activation of a quiescent stem cell population in the NEB ME. The model creates new opportunities for unraveling the cellular mechanisms/pathways regulating silencing, activation, proliferation and differentiation of this unique postnatal airway epithelial stem cell population.
\end{abstract}

Keywords: Airway epithelium, Neuroepithelial body microenvironment, Stem cell niche, Clara-like cells, Pulmonary neuroendocrine cells, Lipopolysaccharide, Proliferation

\section{Background}

The postnatal lung is a conditionally renewing organ with a very low airway epithelial cell turnover in the absence of injury, with less than $1 \%$ of cells dividing at any time point in several species $[1,2]$. However, the lungs and airways are capable of rapidly increasing regeneration rate to replace damaged tissue, with local stem and progenitor cells re-entering the cell cycle (for reviews see $[3,4])$. Adult stem cells are defined as rare cells present in different niches, with a high proliferative potential and a lifelong ability to self-renew, maintain a

\footnotetext{
* Correspondence: dirk.adriaensen@uantwerpen.be

Laboratory of Cell Biology and Histology, Department of Veterinary Sciences, University of Antwerp, Universiteitsplein 1, 2610 Wilrijk, Antwerpen, Belgium
}

variety of cell populations in the steady state and/or replace damaged cells following injury $[3,5,6]$.

Neuroepithelial bodies (NEBs) occur in the airway epithelium as densely innervated clusters of pulmonary neuroendocrine cells (PNECs; for review see [7]). In many species (including humans) PNECs are covered by Clara-like cells (CLCs), leaving only thin apical processes of PNECs in contact with the airway lumen. CLCs, PNECs and their extensive innervation together constitute the so-called 'NEB microenvironment (NEB ME)' [8-11]. CLCs have also been referred to as variant Clara cell secretory protein (CCSP)-expressing cells (vCE cells) [12].

The clusters of PNECs release bioactive substances upon stimulation [13-18] and are selectively contacted by mainly vagal afferent nerve terminals $[9,19]$. Pulmonary

(C) The Author(s). 2018 Open Access This article is distributed under the terms of the Creative Commons Attribution 4.0 International License (http://creativecommons.org/licenses/by/4.0/), which permits unrestricted use, distribution, and 
NEBs should therefore be regarded as complex intraepithelial sensory airway receptors, capable of sensing and transducing hypoxic, mechanical, chemical and likely also other stimuli $[14,15,20]$ (for reviews see [9, 21-23]).

Apart from being airway sensors, NEBs may fulfill some other proposed physiological roles in the airways during fetal and perinatal life [21, 22, 24-26]. The relatively large number of NEBs encountered in the prenatal lung has been explained by their potential role in the regulation of bronchogenesis, as PNECs represent the first cell type that differentiates during embryonic lung development [27]. The possible paracrine regulation of embryonic airway epithelial cell growth by NEBs has been proposed more than 25 years ago based on cell proliferation studies, illustrating that the number of labeled divided cells progressively decreases with increasing distance from NEBs [28].

Throughout the past decade, the NEB ME has been put forward as one of the potential stem cell sources/ niches that are dispersed along the epithelial lining of the mammalian respiratory tract [29-32].

The suggested stem cell capacities of the NEB ME in healthy postnatal mouse lungs were recently confirmed using an optimized laser microdissection (LMD) protocol that allows for the selective collection of high quality mRNA samples of the NEB ME [33]. Expression analysis of an extensive panel of genes, selected for their involvement in cell development, proliferation and stem cell signaling, enabled to define a stem cell 'signature' for the NEB ME, an indication that the NEB ME may indeed represent a functional stem cell niche in healthy postnatal mouse airways [33].

Both cell types in the NEB ME, i.e., PNECs and CLCs, have been proposed as potential airway epithelial progenitor cells [12, 34-37]. The observation that NEBs, or at least epithelial cell groups with similar characteristics, show hyperplasia in many airway diseases/disorders [38-40], and seem to play a role as precursors for small cell lung carcinoma (SCLC) $[6,34,41]$, evidently suggests a role for PNECs as airway epithelial progenitors. However, the 'stemness' of PNECs is currently questioned since PNECs on their own were not able to restore the airway epithelium after ablation of both Clara cells (CCs) and CLCs [12]. On the other hand, self-renewing and stem cell characteristics have been assigned to $\mathrm{CLCs} / \mathrm{vCE}$ cells based on lineage-tracing analysis in murine models [12, 42]. During embryonic development, cells surrounding PNECs, i.e., presumptive CLCs, remain undifferentiated [30]. CLCs/vCE cells appear to be resistant to naphthalene ablation because, unlike CCs, they do not express the cytochrome P450 2F2 isozyme [12, 43, 44]. It has been reported that CLCs in postnatal lungs show the capacity to regenerate both CCs and ciliated cells [45, 46], but that severe epithelial injury is required to activate the stem cell niche for repair [2].

Since the postnatal airway epithelium maintains a very low cell turnover at steady state, experimental damage and the follow-up of epithelial repair processes has typically been used to visualize the proliferative potential of different subsets of airway epithelial cells [1, 47]. A variety of models for severe lung injury and airway epithelial damage have been implemented to activate presumed stem cell niches and study consequent repair throughout the lung epithelium (for reviews see [3, 4, $44,48,49]$. So far, nearly all information on the postnatal stem cell and regenerative capacities of the NEB ME, and of CLCs in particular, has also been obtained after severe experimental injury of the airway epithelium by naphthalene or genetic modification that fully ablates $\mathrm{CCs}$, and from the consecutive evaluation of epithelial regeneration [12, 35, 37, 50], even in recent publications [43]. Major disadvantages of these methods, however, are the difficulty to distinguish between pathological and potentially physiological events, and the emergence of additional (undesired) hyperplasia of PNECs that apparently compromises the selectivity of activating stem cells for repair.

On the other hand, it has been well documented that all levels of severity of lung injury can be mimicked in animal models involving the application of lipopolysaccharide (LPS; intratracheal [51-53], intranasal [54], intraperitoneal [55]). In mice, intratracheal LPS instillation causes a rapid (few hours) intrapulmonary inflammatory reaction whose course is dependent of the mouse strain, LPS concentration and serotype used [52, 56, 57]. So far, however, the effects of LPS instillation on airway-associated epithelial stem cell niches have not been investigated.

Main goal of the present study was to create a minimally invasive mouse model for activation of the quiescent stem cell niche of the NEB ME. We will show that a single intratracheal instillation of a low dose of LPS -which appears to cause only a very mild and transient injuryis able to do the job. Both morphological, functional and cell proliferation assays are used to detect and quantify the relevant changes in the NEB ME that are induced by LPS challenge.

\section{Methods \\ Animals}

Lung tissue was obtained both from wild type (WT) C57BL/ $6 \mathrm{~J}$ (WT-Bl6) mice, and from a C57BL/6 J based glutamate decarboxylase 67-GFP (GAD67-GFP) mouse strain that harbors GFP fluorescent pulmonary NEBs [58] (The Jackson Laboratory, Charles River, Saint-Germain-sur-l'Arbresle, France). Both male and female mice, mainly at postnatal day (PD) 21, were used. Three-week-old mice have a much smaller lung volume -but a similar number of NEBs- 
compared to adults, and hence a higher density of NEBs in lung sections, resulting in more efficient studies. The results were however double-checked for adult mice (8-week-old). The young animals were housed together with their mothers in acrylic cages in an acclimatized room (12/12 $\mathrm{h}$ light-dark cycle; $22 \pm 3{ }^{\circ} \mathrm{C}$ ) and were provided with water and food ad libitum. National and international principles of laboratory animal care were followed, and experiments were approved by the local animal ethics committee of the University of Antwerp (ECD 2014-66 and 2017-49). All animals were killed by intraperitoneal (i.p.) injection of an overdose of sodium pentobarbital (Nembutal ${ }^{\circ} 200 \mathrm{mg} / \mathrm{kg}$ bodyweight (BW), CEVA Sante Animale, Brussels, Belgium).

\section{LPS instillation}

Mice were anesthetized with an i.p. injection of medetomidine $\left(0.25 \mathrm{ml} / \mathrm{kg}\right.$ BW; Domitor ${ }^{\circ}, \mathrm{BE}-\mathrm{V} 151742$, Orion Pharma, Mechelen, Belgium) and ketamine $(17.5 \mathrm{ml} / \mathrm{kg}$ BW; Nimatek ${ }^{\circ}$, Eurovet, Bladel, The Netherlands) to obtain a light level of surgical anesthesia, subsequently placed on an intubation table (Hallowell EMC, Pittsfield, USA) and intubated with a soft flexible cannula $(24 \mathrm{G} \times 3 / 4$ "; BD Angiocath; Becton Dickinson; Erembodegem, Belgium) for the intratracheal instillation of $1 \mathrm{mg} / \mathrm{kg}$ BW LPS (LPS; Escherichia coli; O55:B5; L6529, Sigma, Diegem, Belgium) dissolved in $50 \mu \mathrm{l}$ of sterile saline $(0.9 \% \mathrm{NaCl}$; Baxter, Lessen, Belgium). For evaluation of the potential effects of intratracheal instillation itself on the quantified changes in the NEB ME, sham-treated animals received an intratracheal instillation of $50 \mu \mathrm{l}$ of sterile saline. One hundred $\mu \mathrm{l}$ of air was added to every intratracheal instillation of fluid. After completion of the instillation, anesthesia was reversed by administration of the medetomidine inhibitor atipamezole (2 ml/kg BW; Antisedan , BE-V153352, Orion Pharma, Mechelen, Belgium) to ameliorate recovery. Animals were euthanized 16 h, 24 h, 48 h, 72 h or 7 days after challenge, as detailed further on.

\section{BrdU injection}

As an analog of thymidine, 5-Bromo-2'-deoxyuridine (BrdU) will be incorporated in DNA during the S-phase of cell division. To mark cells that have divided during the experimental window, i.p. injections of BrdU (10 mg/kg; B5002; Sigma, Bornem, Belgium) were given immediately following intratracheal instillation in the treated groups, and at the same time point in untreated matched control mice. BrdU injections were repeated at $24 \mathrm{~h}$ and $48 \mathrm{~h}$ post-instillation. After recovery, animals were returned to their mothers until the day of euthanasia, $24 \mathrm{~h}, 48 \mathrm{~h}$ or $72 \mathrm{~h}$ after LPS challenge or any of the other treatments. Additionally, a few mice received BrdU at time points $0 \mathrm{~h}$ and $24 \mathrm{~h}$ but were sacrificed 7 days following LPS instillation. The lungs were then processed for cryosectioning and immunostaining (see further on).

\section{Plethysmography}

Lung function parameters were measured using an unrestrained mouse Whole-Body Plethysmograph (VENT2; EMKA Technologies; Paris, France). Expiratory time (Te), relaxation time (RT), end-inspiratory pause (EIP) and tidal volume (TV) were evaluated at different time points $(1 \mathrm{~h}, 2 \mathrm{~h}, 4 \mathrm{~h}, 6 \mathrm{~h}, 8 \mathrm{~h}, 12 \mathrm{~h})$ after start of the experiment (LPS instillation, sham treatment, untreated controls; WT-Bl6; $n=4$ for each group).

\section{Bronchoalveolar lavage}

Sixteen hours after LPS or sham instillation, WT-Bl6 mice ( $\mathrm{n}=4$ for each group) were euthanized and exsanguinated. Untreated WT-Bl6 mice $(\mathrm{n}=4)$ served as an additional control. Bronchoalveolar lavage fluid (BALF) was collected by instillation and suction of a salt solution $(2 \times 1 \mathrm{ml} ; 0.9 \% \mathrm{NaCl})$ in the lungs via a tracheal cannula. BALF was stored at $4{ }^{\circ} \mathrm{C}$ until further use. In accordance with literature [59], the time point of $16 \mathrm{~h}$ after LPS treatment was chosen to allow the animals to recover completely from the anesthetics and still be able to detect effects from a combination of early and late phase mediators in the BALF. The collected BALF was first centrifuged (12 $\mathrm{min}, 150 \mathrm{G})$, the cell-free supernatant fluid was removed and used as a stimulus solution for the NEB ME in lung slices in live cell imaging (LCI) experiments (see below). The cell pellet was used to prepare cytospin slides for evaluation of the cells that are present in the pulmonary air spaces. The pellet was resuspended to an end concentration of about $10^{6}$ cells $/ \mathrm{ml}$ in phosphate-buffered saline (PBS; $0.01 \mathrm{M}, \mathrm{pH} 7.4$ ), containing $5 \%$ bovine serum albumin (BSA; B4287, Sigma). $150 \mu \mathrm{l}$ of this mixture was centrifuged ( $5 \mathrm{~min}, 800 \mathrm{G}$ ) to generate cytospin preparations (Shandon Cytospin 3 Cytocentrifuge, Fisher Scientific, Erembodegem, Belgium) of BALF cells. After air-drying, the slides were fixed and stained using a fast routine blood cell staining method (Diff-Quick; DQ-ST, MICROPTIC, Barcelona, Spain), and mounted in Entellan (Merck; Overijse, Belgium). Cell types in the BALF cytospins were morphologically characterized under a light microscope and compared between LPS-challenged, sham-treated and untreated controls. Data were used only for general interpretation of the inflammatory effect of instillation, and no further quantification was performed.

\section{Preparation of live lung slices}

Live lung slices were prepared as previously published [60]. In short, WT-Bl6 mice $(n=3)$ were euthanized and the lung tissue was stabilized by slowly instilling a $2 \%$ agarose solution $\left(37{ }^{\circ} \mathrm{C}\right.$, low-melt agarose, A4018, Sigma) via a tracheal cannula. After inflation, lungs were dissected and transferred to an ice-cold physiological solution. Precision-cut lung slices $(120 \mu \mathrm{m}$ thick $)$ were 
sectioned using a vibratome (Microm HM650 V; Microm International, Walldorf, Germany) and 6-8 slices per animal were subsequently kept in the cold physiological solution until further manipulation within the next few hours (maximally $6 \mathrm{~h}$ ).

\section{Live cell imaging}

As previously reported in detail [8], different cell types in the NEB ME and in the surrounding airway epithelium, such as PNECs, CLCs, CCs and ciliated cells, can be identified in live lung vibratome slices after staining with the fluorescent dye 4-Di-2-ASP (Molecular Probes D-289, Fisher Scientific) and loading with the $\mathrm{Ca}^{2+}$ indicator Fluo-4 AM (Molecular Probes F-14202; Fisher Scientific). In short, lung slices were consecutively incubated for $4 \mathrm{~min}$ in $4 \mu \mathrm{M}$ 4-Di-2-ASP in Dulbecco's modified Eagle's medium/F-12 (DMEM-F-12; Gibco, Fisher Scientific) at $37{ }^{\circ} \mathrm{C}$, rinsed, and incubated for $1 \mathrm{~h}$ at room temperature in $10 \mu \mathrm{M}$ Fluo-4 AM. For experimental LCI purposes, the lung slices were submerged in a tissue bath $(2 \mathrm{ml})$ mounted on the microscope stage, continuously perfused with physiological solution by a gravity-fed system (flow rate of $0.5 \mathrm{ml} / \mathrm{min}$ ). Perfusion was paused when BALF was manually pipetted onto the lung slice in the tissue bath. Physiological solution containing a high extracellular potassium concentration $\left(\left[\mathrm{K}^{+}\right]_{\mathrm{o}}\right)$ was prepared by equimolar substitution of $\mathrm{KCl}$ for $\mathrm{NaCl}[8]$.

High-resolution LCI was performed as extensively described before $[8,13,60]$. In short, a microlensenhanced dual spinning disk confocal system (UltraVIEW ERS; PerkinElmer, Zaventem, Belgium), equipped with an argon-krypton laser was used. Time-lapse images of changes in Fluo-4 fluorescence (excitation max. $494 \mathrm{~nm}$; emission max. $516 \mathrm{~nm}$ ) were recorded (2 images/s; 488-nm laser excitation; bandpass 500-560 emission filter) and analyzed off-line by Volocity 2 software (Improvision, Coventry, UK). Regions of interest were manually drawn around identified cell groups of interest, and the fluorescence intensity was plotted against time. Changes in Fluo-4 fluorescence should be interpreted as relative changes in the intracellular $\mathrm{Ca}^{2+}$ concentration $\left(\left[\mathrm{Ca}^{2+}\right]_{\mathrm{i}}\right)$. All graphs presented are representative of multiple experiments performed under the respective conditions.

\section{Immunohistochemical staining of lung cryosections for the evaluation of cell division}

All mice included in the LPS challenge experiments, including sham-treated and untreated controls, were processed for cryosectioning and immunostaining as detailed below. Mice were euthanized and the lungs were transcardially perfused with physiological solution and subsequently filled with $4 \%$ paraformaldehyde (PF) via a tracheal cannula. Lungs, trachea, esophagus and heart were dissected en bloc, deaerated in a mild vacuum, and immersion-fixed in the same fixative for $30 \mathrm{~min}$. After rinsing in PBS, tissues were stored overnight in $20 \%$ sucrose (in PBS; $4{ }^{\circ} \mathrm{C}$ ), and mounted in Tissue-Tek O.C.T. (4583; Sakura Finetek Europe, Zoeterwoude, The Netherlands). Consecutive cryostat sections (20 $\mu \mathrm{m}$ thick; Leica CM1950, Diegem, Belgium) of the whole tissue blocks were thaw-mounted on poly-L-lysine-coated microscope slides following a strict pattern (see further on), dried at $37{ }^{\circ} \mathrm{C}(2 \mathrm{~h})$ and kept at $-80{ }^{\circ} \mathrm{C}$ until further use.

Immunohistochemical incubations were performed at room temperature in a closed humidified container. All primary and secondary antisera were diluted in PBS containing 10\% normal horse serum and 0.1\% BSA (PBS*). Before incubation with the primary antisera, cryostat sections were permeabilized for $1 \mathrm{~h}$ with PBS* containing 1\% Triton X-100. Sections were then incubated overnight with a combination of the primary antibodies listed in Table 1. For visualization of the immunolabeling, sections were further incubated for $4 \mathrm{~h}$ with secondary antibodies (Table 2).

After a final wash in PBS, the sections were mounted in Citifluor (19,470; Ted Pella, Redding, CA).

For each animal, a few cryosections were routinely stained with hematoxylin and eosin (H\&E), dehydrated in a graded series of ethanol and xylene, and mounted in Entellan. Lung sections were evaluated under a light microscope for the histological evaluation of epithelial damage, interstitial inflammation, edema and leukocyte recruitment, as characteristics of pulmonary inflammation and lung injury [61].

A bright-field/epifluorescence microscope (Zeiss Axiophot, Carl Zeiss, Jena, Germany) was used to image the H\&E-stained lung cryosections and DiffQuick stained BALF cytospins, and to quickly screen the immunostaining results. All fluorescence images were obtained using a microlens-enhanced dual spinning disk confocal microscope (UltraVIEW VoX; PerkinElmer) equipped with $488 \mathrm{~nm}, 561 \mathrm{~nm}$ and $640 \mathrm{~nm}$ diode lasers for excitation of

Table 1 List of primary antisera used for immunohistochemistry

\begin{tabular}{llll}
\hline $\begin{array}{l}\text { Primary Antisera } \\
\text { Antigen }\end{array}$ & Host & Mc/PC & Source \\
\hline $\begin{array}{llll}\text { Bromo deoxyuridine (BrdU) } \\
\text { Calcitonin gene-related }\end{array}$ & Rat & Mc & $\begin{array}{l}\text { Abcam ab6326, } \\
\text { Cambridge, UK }\end{array}$ \\
$\begin{array}{l}\text { peptide (CGRP) } \\
\text { CGRP }\end{array}$ & PC & $\begin{array}{l}\text { Sigma C3866, } \\
\text { Bornem, Belgium }\end{array}$ \\
$\begin{array}{l}\text { Urine protein 1 (UP1)/Clara } \\
\text { cell secretory protein (CCSP) }\end{array}$ & Rabbit & PC & Abcam ab36001 \\
\hline
\end{tabular}


Table $\mathbf{2}$ List of secondary antisera used for immunohistochemistry

\begin{tabular}{|c|c|c|}
\hline Secondary Antisera & Source & Dilution \\
\hline \multicolumn{3}{|l|}{ Antigen } \\
\hline $\begin{array}{l}\text { Cy }{ }^{\mathrm{TM} 5} \text {-conjugated Fab } \\
\text { fragments of goat } \\
\text { anti-rabbit lgG }\end{array}$ & $\begin{array}{l}\text { Jackson ImmunoResearch } \\
111-117-003, \\
\text { West Grove, PA, USA }\end{array}$ & $1 / 2000$ \\
\hline $\begin{array}{l}\text { Cy }^{\mathrm{TM} 3-c o n j u g a t e d} \\
\text { donkey anti-rat IgG }\end{array}$ & $\begin{array}{l}\text { Jackson ImmunoResearch } \\
712-165-153\end{array}$ & $1 / 1000$ \\
\hline $\begin{array}{l}\text { FITC-conjugated } \\
\text { donkey anti-goat lgG }\end{array}$ & $\begin{array}{l}\text { Jackson ImmunoResearch } \\
\text { 705-095-147 }\end{array}$ & $1 / 500$ \\
\hline $\begin{array}{l}\text { Cy }{ }^{\text {TM5-conjugated }} \\
\text { donkey anti-rabbit lgG }\end{array}$ & $\begin{array}{l}\text { Jackson ImmunoResearch } \\
711-175-152\end{array}$ & $1 / 500$ \\
\hline
\end{tabular}

FITC/GFP, Cy3 and Cy5. Images were acquired and processed using Volocity 6.3.1 software (PerkinElmer).

\section{Data acquisition, quantification and statistics}

Quantification of the BrdU-positive cells was performed by manually counting the fluorescent nuclei in the areas of interest. Lung cryosections (20 $\mu \mathrm{m}$-thick) were collected and selected in a reproducible manner. Per slide, two sections were mounted in such a way that the distance between both sections is $200 \mu \mathrm{m}$. In short, ten consecutive sections were mounted on different slides, after which the following 10 sections were mounted in the same order on these slides. The next 20 consecutive sections were collected on 10 new slides, and so on until the lung tissue was completely cut. Then, a first slide for staining was selected based on the presence of airway branches and presumably NEBs. Starting from this slide, six more were taken every 10 slides, thereby avoiding the possibility that more than one section of the same NEB ME could be found and/or counted in the selected slides when immunostained for BrdU and some reference markers. As such, for every mouse in the different treatment groups (LPS-treated, sham treated and untreated control), between 60 and 100 NEBs were visualized under the microscope, by their GFP fluorescence in GAD67-GFP mice or CGRP immunostaining in WT-Bl6 mice, and the PNECs and BrdU-positive cells in the NEB ME were counted.

For each animal in all of the experimental groups, the mean number of BrdU-positive cells per NEB ME was calculated and the data were statistically compared between the different treatment groups, using a nonparametric Kruskal-Wallis test followed by Dunn's multiple comparisons test. Data are represented as (mean \pm SEM).

Potential differences in the number of BrdU-positive cells between the two mouse strains were statistically evaluated using the unpaired t-test for each treatment group, after checking normal distribution of the counts.

\section{Results}

Evaluation of the pulmonary effects of low dose LPS challenge

Although the recorded plethysmographic data did not qualify for quantification, due to individual variation inherent to the use of unrestrained young mice, some of the observations were of importance for the presented study. Apart from clear but variable differences in the measurements of TE, RT, EIP and TV between untreated controls and LPS-challenged (and to a lesser extent also sham-treated) mice during the first 2 to $6 \mathrm{~h}$, plethysmography could no longer distinguish LPS-challenged from untreated animals $8 \mathrm{~h}$ or longer after treatment (data not shown).

To assess possible inflammatory changes in the airway environment, BALF was collected from the same animals that had been monitored by plethysmography (16 h after instillation of LPS or saline and untreated), and processed for the generation of cytospin preparations. While BALF of healthy control animals showed macrophage-like cells only (Fig. 1a), the majority of leukocytes in the LPS-treated mice appeared to be neutrophils (Fig. 1c, d). Neutrophils were also seen in BALF of the sham-treated mice (Fig. 1b), but clearly to a lesser extent than after LPS challenge.

The applied single low-dose intratracheal LPS challenge did not cause obvious histological changes in the airway epithelium or alveolar areas in $\mathrm{H} \& \mathrm{E}$-stained lung sections (Fig. 2).

An important element for the interpretation of the following experimental data is that this combined approach (plethysmography, evaluation of the collected BALF; lung histology), supports the idea that the applied single low dose of intratracheal LPS induces a mild and transient inflammation.

\section{Application of BALF from LPS-challenged mice to the NEB ME of healthy control mice}

Apart from detecting/recording $\left[\mathrm{Ca}^{2+}\right]_{\mathrm{i}}$ fluctuations in the NEB ME, freshly cut live lung slices co-loaded with 4-Di-2-Asp and Fluo-4, also allowed to differentiate between all cell types in the NEB ME and the surrounding airway epithelium (for detailed explanation see [8]). In short, very small and moderately fluorescent grouped NEB cells are encircled by a virtually non-fluorescent rim that harbors much larger CLCs, and are further surrounded by intermingled strongly fluorescent polygonal ciliated cells and large rounded unstained CCs (Fig. 3b).

To allow fast evaluation of the effect of LPS-induced inflammatory mediators on the NEB ME, BALF that had been collected from mice $16 \mathrm{~h}$ after intratracheal instillation of LPS, was applied to lung slices of healthy control mice in the course of the LCI experiments.

BALF of LPS-treated mice was seen to induce a reversible and reproducible $\left[\mathrm{Ca}^{2+}\right]_{\mathrm{i}}$ rise, selectively in CLCs 


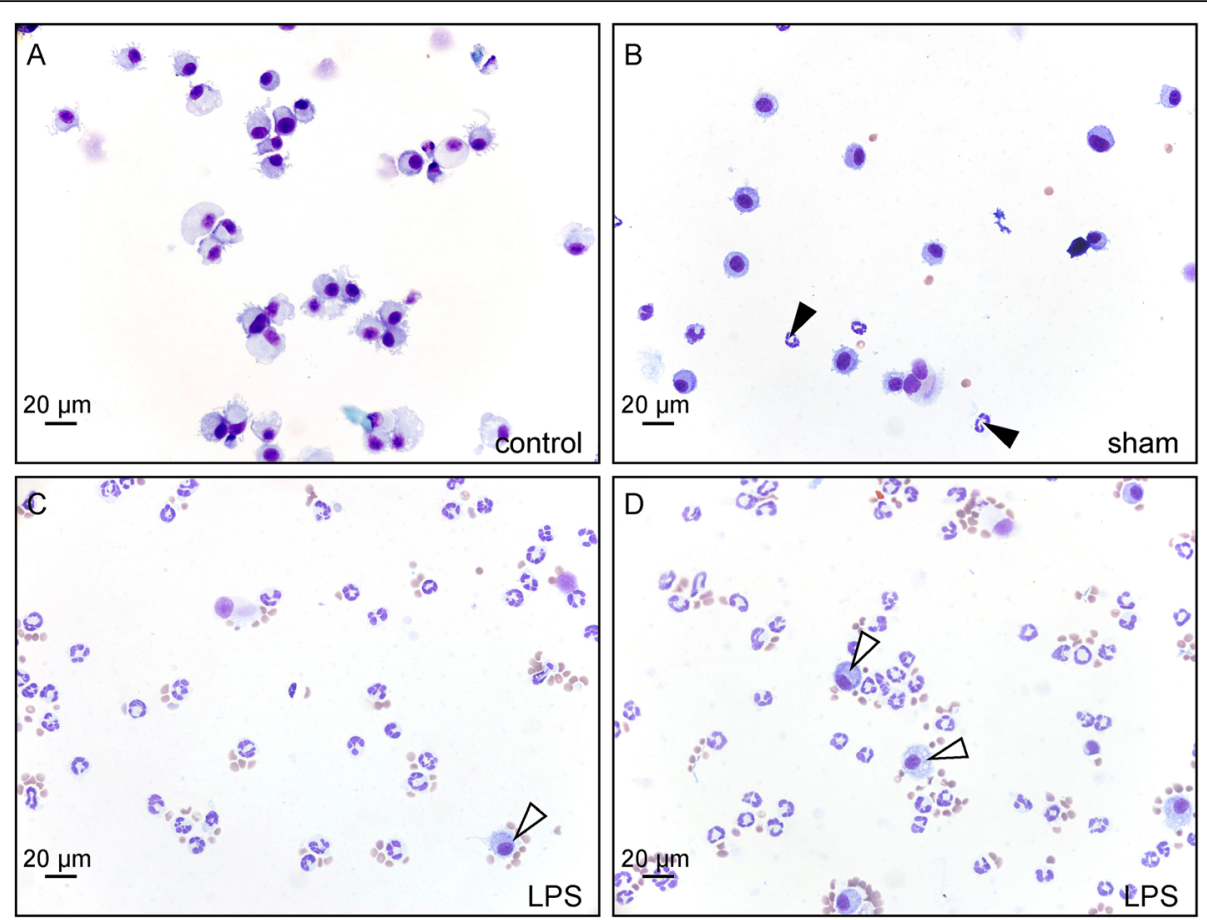

Fig. 1 Representative images, with similar cell densities, of Diff-Quick-stained cytospin preparations of BALF collected from mice that received no instillation (untreated healthy control animal; a), 16 h after an intratracheal instillation with $0.9 \% \mathrm{NaCl}$ (sham-treatment; b), or with LPS (c, d). Cell densities of the cytospin preparations were 'normalized' between the experimental groups and are therefore unrelated to the initial cell numbers in the BALF. a BALF of a healthy control mouse contains virtually no other cells than macrophages (acentric oval nuclei and bluish cytoplasm). b Some neutrophils (segmented nuclei and unstained cytoplasm; arrowheads) appear to be infiltrated in the airways after a sham instillation but macrophages still constitute the majority of cells in this sample. $\mathbf{c}$, $\mathbf{d}$ Massive neutrophil influx is seen as a response to the LPS instillation, and consequently a relatively low number of macrophages (open arrowheads). Note that the preparations of treated animals also harbor some red blood cells (small brownish dots)
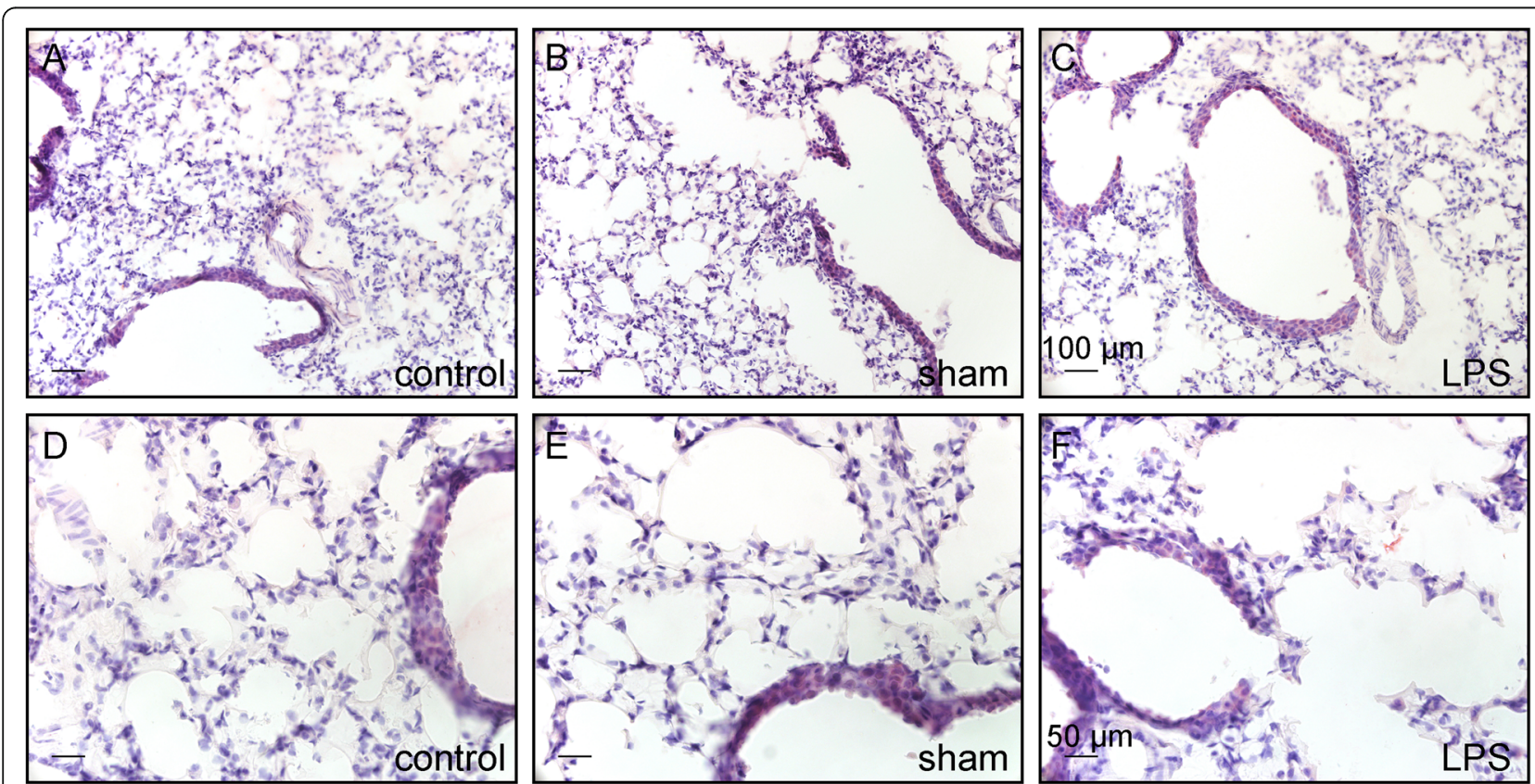

Fig. 2 Representative images of HE-stained lung cryosections from untreated control (a, d), and $48 \mathrm{~h}$ after intratracheal instillation with $0.9 \% \mathrm{NaCl}$ (sham-treatment; $\mathbf{b}, \mathbf{e})$, or with LPS (c, $\mathbf{f})$. Note that lung morphology shows no clear histological differences between the groups 


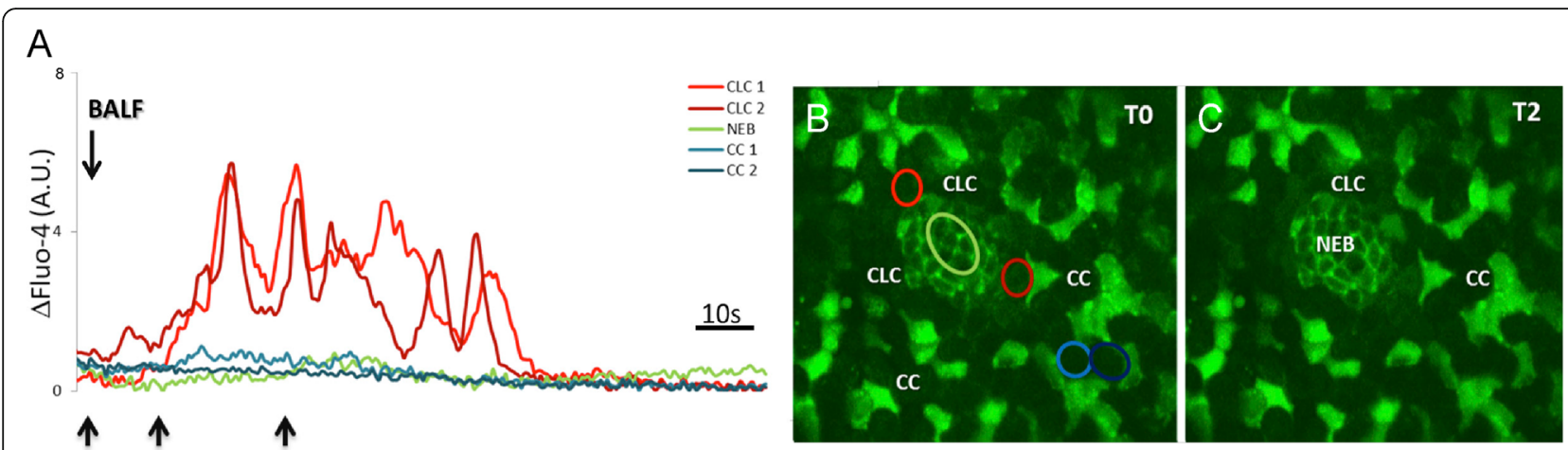

T0 T1 T2

Fig. $3 \mathrm{LCl}$ representation of the effects of application of BALF of an LPS-challenged mouse to the NEB ME in a vibratome cut live lung slice of a control mouse. a Graphs plotting the time course of Fluo-4 fluorescence intensity, as an indicator for $\left[\mathrm{Ca}^{2+}\right]_{\text {i, }}$ in different cell types in the airway epithelium. To facilitate interpretation, grey levels of each region of interest (ROI) were adjusted for the basal level of (background) fluorescence at the start of imaging. After application of BALF $(=T 0), C L C s$ that surround the NEB cells show a calcium-mediated activation within about $10 \mathrm{~s}$ $(=\mathrm{T} 1)$. The oscillating $\left[\mathrm{Ca}^{2+}\right]_{i}$ rise in $\mathrm{CLCs}$ continues $(=\mathrm{T} 2)$ for more than a minute post-exposure. No changes in $\left[\mathrm{Ca}^{2+}\right]_{i}$ can be observed in NEB cells or CCs. $\mathbf{b}$, c Corresponding pseudo-color time-lapse images of Fluo-4 fluorescence at two time points $(B=T 0 ; C=T 2)$ after the application of BALF. Note that the ROIs corresponding to the graphs in (a) are represented in the same color code in image $\mathbf{b}$

of the NEB ME (Fig. 3). CLCs appeared to react within about $10 \mathrm{~s}$ after administration of BALF and revealed $\left[\mathrm{Ca}^{2+}\right]_{\mathrm{i}}$ oscillations for about a minute. On the other hand, NEB cells, CCs and ciliated cells did not show a $\left[\mathrm{Ca}^{2+}\right]_{\mathrm{i}}$ rise. Comparable challenge of lung slices with LPS $(15 \mu \mathrm{g} / \mathrm{ml}$ in physiological solution) or with BALF of sham and untreated control mice did not induce a $\left[\mathrm{Ca}^{2+}\right]_{\mathrm{i}}$ rise in any cell type in the NEB ME or airway epithelium, while the physiological responsiveness of the lung slices could be confirmed by the typical fast and reversible $\left[\mathrm{Ca}^{2+}\right]_{\mathrm{i}}$ increase in NEB cells and a slightly delayed $\left[\mathrm{Ca}^{2+}\right]_{i}$ rise in CLCs, following a 5-s application of $50 \mathrm{mM} \mathrm{K}^{+}$(not shown) [8].

\section{Effects of a single intratracheal instillation with LPS and} the resulting transient mild inflammation on the NEB ME The above observation that CLCs- which are presumed quiescent airway epithelial stem cells in healthy control mice - show a calcium-mediated activation upon short-term application of BALF that contains soluble mediators from the airways of LPS-challenged mice, raised the question as to what the effects might be on CLCs that experience long-term exposure to these mediators in airways of LPS-treated mice. To follow up on the hypothesis that activation of quiescent (non-dividing) stem cells might be linked to proliferation, the potential effect of intratracheal administration of a single low dose of LPS on airway epithelial cell proliferation in general, and on the NEB ME in particular, was monitored using simultaneous BrdU incorporation as a marker for cells that divide during the experimental window. Three experimental groups were included: untreated control mice, mice receiving an intratracheal instillation with LPS, and mice with an intratracheal instillation of a $0.9 \% \mathrm{NaCl}$ solution (= sham control).

In cryosections of the lungs of untreated healthy 3-week-old WT-Bl6 mice, hardly any divided cells were discerned in control airway epithelium (CAE) within the investigated time windows (24, 48 (Fig. 4 a) or 72 h) as confirmed by BrdU labeling. The very rare divided epithelial cells appeared to be randomly distributed. The majority of cells with BrdU-labeled nuclei in the airways of these untreated controls were found subepithelially (Fig. 4a). As a positive control, BrdU incorporation was evaluated in sections of a piece of small intestine that was additionally collected from each mouse. A large number of divided (BrdU-labeled) epithelial cells was invariably observed in crypts of the intestinal villi (Fig. 4b).

Forty-eight hours after a single intratracheal instillation with low-dose LPS, a considerable number of divided (BrdU-positive) epithelial cells was detected, typically clustered in distinct areas of the airway epithelium of WT-Bl6 mice (Fig. 5a).

In sham-treated WT-Bl6 mice, BrdU-positive cells also appeared to be more numerous at specific locations in the airway epithelium (Fig. 5c) than in untreated controls, although the increase was less pronounced than that seen in LPS-treated mice.

Double immunostaining of the BrdU-labeled sections for CGRP, as a marker for NEBs, revealed that the great majority of divided airway epithelial cells were located in the NEB ME following LPS challenge (Fig. 5b, d).

All of the above data were obtained using 3-week-old mice, but a similar selective cell proliferation (BrdU positive nuclei) in the NEB ME was observed in LPS-challenged adult mice (not shown). 

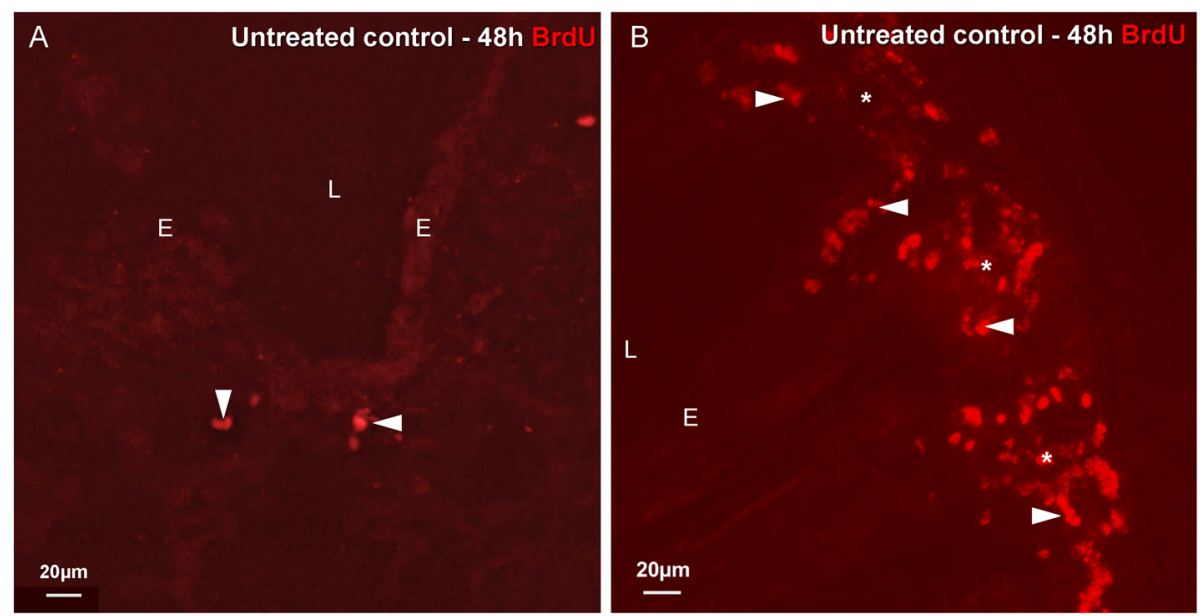

Fig. 4 Immunostaining for BrdU (red Cy3 fluorescence) in cryosections of an intrapulmonary airway (a) and small intestine (b) of the same mouse that received no treatment, except for the BrdU injections (i.p.), $48 \mathrm{~h}$ and $24 \mathrm{~h}$ prior to sacrifice. a The airway epithelium rarely harbors divided BrdU-positive cells. The majority of BrdU-labeled nuclei (arrowheads) are located in subepithelial layers. $\mathbf{b}$ In the crypts (asterisks) and the basal parts of the villus epithelium of the small intestine, a large number of BrdU-labeled nuclei (arrowheads)-i.e., originating from cells that have divided during the $48 \mathrm{~h}$ experimental windowt can be observed. L: airway lumen, E: airway epithelium

Given the apparent close link between NEBs and divided (BrdU-labeled) epithelial cells in the airways of LPS-challenged mice, the use of GAD67-GFP mice that harbor intrinsically GFP-fluorescent NEBs [58] would offer considerable advantages for further quantification. Therefore, we verified whether similar results could be obtained in WT-B16 and GAD67-GFP mice. Comparable to what was seen using WT-Bl6 mice with CGRP as a NEB marker (Figs. 5a, b and 6a, b), LPS-treated GAD67GFP mice also showed BrdU-labeled (divided) airway epithelial cells that were selectively grouped around GFP-fluorescent NEBs (Fig. 6c, d).

Both in healthy controls, sham-treated and LPSchallenged mice, the numbers of CGRP- or GFP-positive PNECs with BrdU-positive nuclei were very low after $48 \mathrm{~h}$ exposure.

Since the majority of proliferating (BrdU-labeled) airway epithelial cells in LPS-treated mice was located in the NEB ME, closely surrounding NEB cells, and because BALF of LPS-challenged mice was seen to selectively activate CLCs in the NEB ME, we further investigated whether BrdU-positive cells co-label with markers for CCs/CLCs.

\section{Characterization of the cell type(s) that typically divide in the NEB ME following LPS challenge}

To further confirm the identity of BrdU-labeled cells in the NEB ME as CLCs, lung sections (48 $\mathrm{h}$ after LPS instillation) were additionally immunostained for CCSP, a marker of both CCs and CLCs surrounding NEB cells. CCSP was used due to the lack of a selective marker for CLCs in postnatal lungs and revealed that cells with BrdU-labeled nuclei in the NEB ME invariably co-stained for CCSP (Fig. 7c), confirming that mainly CLCs were concerned.
Selection of the most relevant time window to study cell proliferation in the NEB ME following LPS challenge Because single intratracheal instillation of LPS appeared to specifically induce cell division (BrdU incorporation) in the NEB ME in a $48 \mathrm{~h}$ time window, we next evaluated whether this was the most relevant time point for visualization/ quantification of cell proliferation in the NEB ME. To this end, three time windows were included in a pilot experiment; lungs were collected $24 \mathrm{~h}, 48 \mathrm{~h}$ and $72 \mathrm{~h}$ after LPS challenge. Our preliminary data revealed BrdU-labeled airway epithelial cells in the NEB ME already after $24 \mathrm{~h}$, although the effect appeared to be much more prominent $48 \mathrm{~h}$ after LPS challenge (Figs. 5a,b, 6 and 7). After $72 \mathrm{~h}$, some of the BrdU-labeled epithelial cells were located a few cells away from NEBs, making this time window somewhat less selective for the NEB ME.

Interestingly, 7 days after LPS challenge, BrdU-positive nuclei could still be detected in CCSP-positive CLCs in the NEB ME, similar to what was seen after $48 \mathrm{~h}$, but also in CCSP-labeled CCs in the surrounding airway epithelium (Fig. 8).

Because the NEB ME is the main area of interest for the present investigation, and considering the observed calciummediated activation of CLCs, the time window of $48 \mathrm{~h}$ BrdU incorporation after LPS challenge was chosen for further quantification of cell proliferation in the NEB ME.

Quantitative analysis of BrdU-labeled cells in the NEB ME after LPS treatment

Evaluation of potential differences between WT-BI6 and GAD67-GFP mice

Cell division was quantified in a $48 \mathrm{~h}$ time window using WT-Bl6 and GAD67-GFP mice that had been injected 

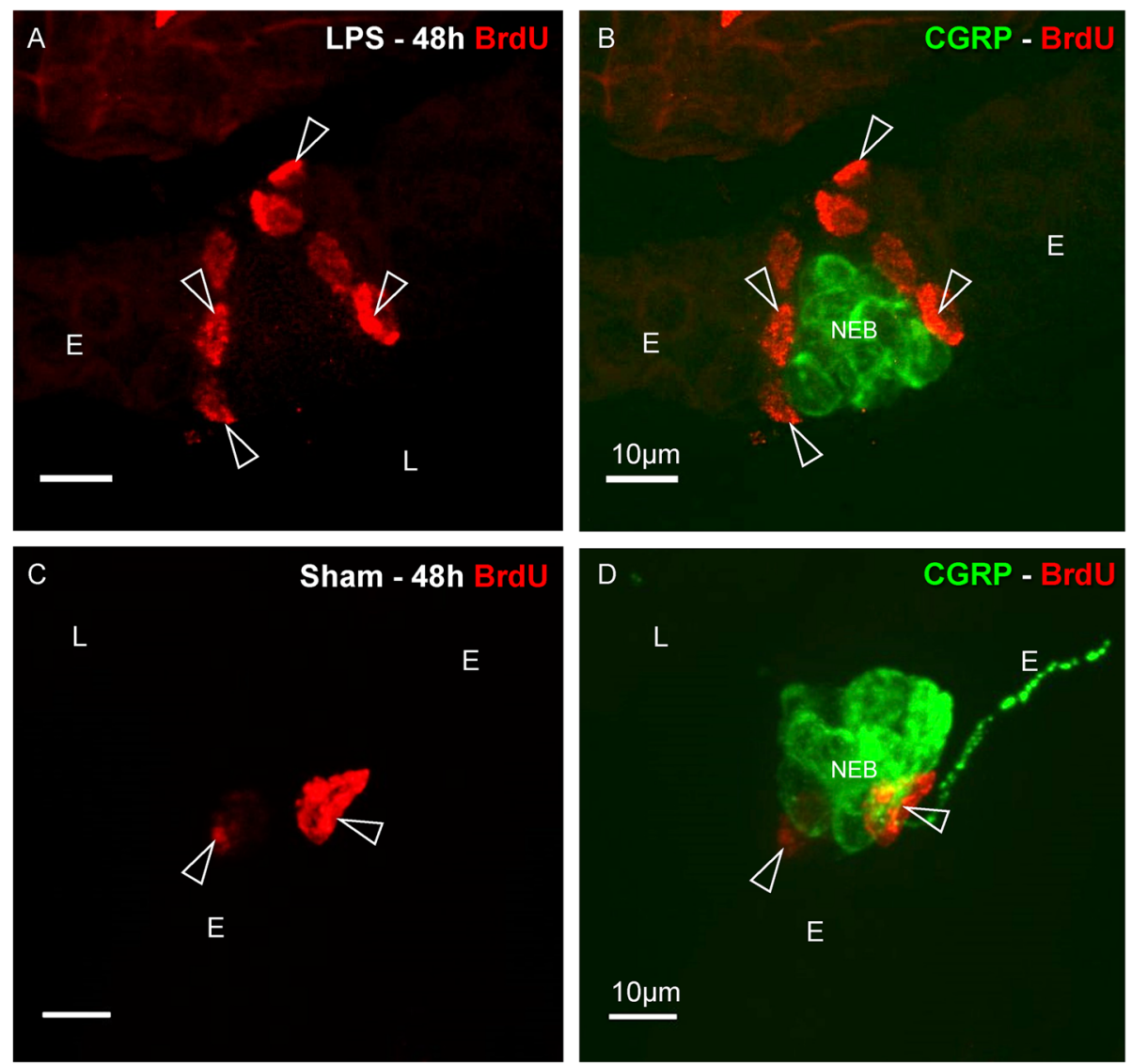

Fig. 5 Immunostaining for BrdU (red Cy3 fluorescence) and CGRP (green FITC fluorescence) in intrapulmonary airways $48 \mathrm{~h}$ after an intratracheal LPS (a, b) or sham instillation (c, d) in WT-Bl6 mice. a After LPS challenge, clustered BrdU-positive (divided) cells are observed in the epithelial layer (open arrowheads). $\mathbf{b}$ Additional CGRP immunostaining reveals that the intraepithelial BrdU-labeled cells are typically grouped around NEBs. c, d After a sham instillation, intraepithelial BrdU-positive cells also appear to be located in the neighborhood of NEBs (open arrowhead), but are less numerous than after LPS treatment. L: airway lumen, E: airway epithelium

with BrdU at time point zero and after $24 \mathrm{~h}$. Three groups were included, i.e., mice receiving a single intratracheal injection with either LPS or $0.9 \% \mathrm{NaCl}$ at time point zero, and untreated control mice.

To avoid that unlikely variations in cell proliferation between WT-Bl6 mice and GAD67-GFP mice would hamper the interpretation of observed differences, both mouse strains were included in the quantifications.

The significance of possible variations between GAD67-GFP $(n=5)$ and WT-Bl6 $(n=5)$ mice was evaluated by means of a nonparametric t-test on the percentages of NEBs that showed BrdU-positive cells for the two treatment groups (LPS-challenged WT-Bl6: $72.2 \pm$ $4.4 \%$ vs. LPS-challenged GAD67-GFP mice: $61.9 \pm$ $2.1 \%, p=0.1$; sham-treated WT-Bl6: $23.2 \pm 2.6 \%$ vs. sham-treated GAD67-GFP mice: $19.3 \pm 3.5 \%, p=0.4$ ) and on the mean number of BrdU-positive cells per activated NEB ME (LPS-challenged WT-Bl6: $3.45 \pm 0.37$ vs. LPSchallenged GAD67-GFP mice: $3.30 \pm 0.26, p=0.1$; shamtreated WT-Bl6: $1.54 \pm 0.53$ vs. sham-treated GAD67-GFP mice: $1.78 \pm 0.07, p=0.4)$. Consequently, data for the two strains could be pooled for further quantification of the potential differences between the experimental groups.

\section{Correlation between the number of BrdU-labeled cells and the number of PNECS in NEBS}

To examine whether the size (number of PNECs) of NEBs is important for the number of divided cells in the NEB $\mathrm{ME}$, the number of BrdU-positive cells was plotted out against the number of PNECs for each counted NEB of all animals in the treatment groups. Although the mean number of PNECs per NEB (10.8 \pm 0.6 for LPS-treated animals vs. $11.3 \pm 1.0$ for sham-treated) was, as expected, not significantly different for both groups (unpaired t-test; $p>0.66$ ), the mean number of BrdU-positive cells per NEB ME $(0.5$ \pm 0.1 for sham-treated vs. $2.1 \pm 0.3$ for LPS-treated mice) was significantly higher $(p<0.0005)$ in the LPS-challenged mice (Fig. 9).

Overall, larger NEBs (more PNECs) appeared to harbor in their ME a modestly higher number of cells that 

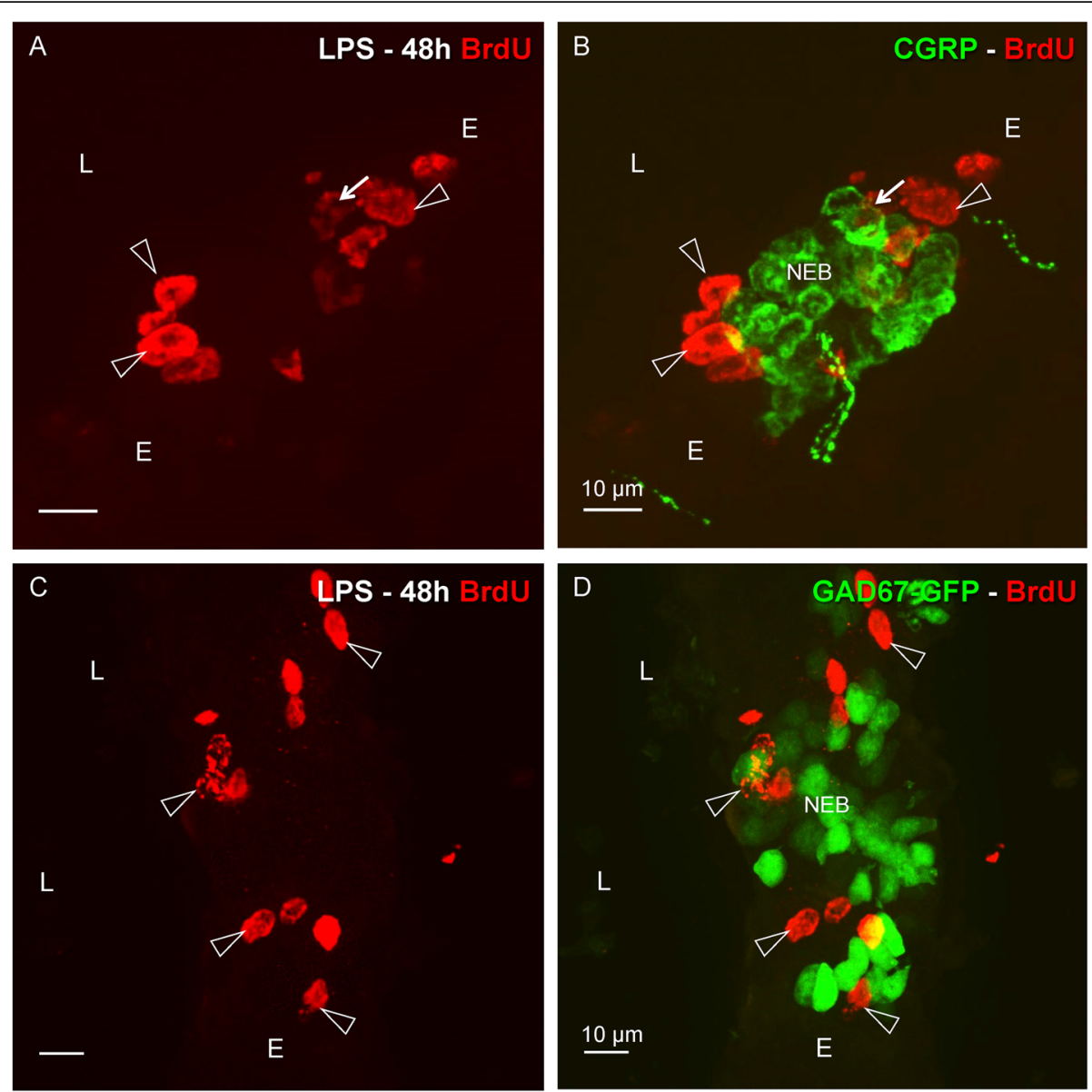

Fig. 6 Comparison of the distribution of BrdU-labeled (red Cy3 fluorescence) airway epithelial cells $48 \mathrm{~h}$ after LPS challenge of WT-Bl6 (a, b) and GAD67-GFP mice (c, d). a, c Clustered BrdU-positive nuclei (open arrowheads) can be observed at distinct locations in the airway epithelium. Combination with CGRP immunostaining (b; green FITC fluorescence) for WT-Bl6 mice, or visualization of GFP-fluorescent NEB cells (d) in GAD67GFP mice, reveals that the majority of divided cells that have incorporated BrdU are found in the immediate neighborhood of NEBs. No obvious differences can be seen between WT-BI6 and GAD67-GFP mice. Note that only very occasionally, a BrdU-positive nucleus can be seen in a NEB cell (arrow; a, b). L: airway lumen, E: airway epithelium

have divided during a $48 \mathrm{~h}$ time window, although only a small non-significant positive trend in the correlation between the number of PNECs and the number of divided cells in the NEB ME was observed for the complete set of quantified NEBs in both treatment groups (sham-treated: $r=0.20$; LPS-treated mice: $r=$ 0.31; Fig. 9).

Further quantifications were therefore carried out without additional analysis of the number of PNECs in each NEB.

\section{Percentage of NEBs that harbor divided cells in their ME}

Extensive quantification of BrdU-labeled (divided) cells in the NEB ME in the airways of LPS-challenged, sham-treated and untreated controls revealed clear differences between the experimental groups (Fig. 10). Mice that received an intratracheal LPS instillation harbored a significantly higher mean percentage (Non-parametric Kruskal-Wallis test) of
NEBs with BrdU-positive cells in their ME (72.2 $\pm 2.4 \%)$, as compared to sham-treated animals $(23.2 \pm 2.6 \%)$ and untreated control mice $(9.2 \pm 2.4 \%)$.

\section{Number of divided cells per NEB ME}

A closer look at the number of BrdU-stained cells (framed areas in Fig. 10; Table 3) did not show clustering of divided cells in the NEB ME in untreated control mice (mean number of BrdU-positive cells for all NEBs with divided cells: $1.14 \pm 0.3$ BrdU-positive cells/NEB $\mathrm{ME}$; total of 10.5 BrdU-positive cells/100 NEBs). In the sham experiments, relatively more NEBs showed divided cells in their ME, but similar to the untreated controls they were mainly observed as solitary BrdU-stained cells (mean number: $1.51 \pm 0.26$ BrdU-positive cells/NEB ME; total of 35 BrdU-positive cells/100 NEBs). However, clustering of divided cells in the NEB ME was seen after LPS treatment, with $40 \%$ of the NEBs harboring three to 


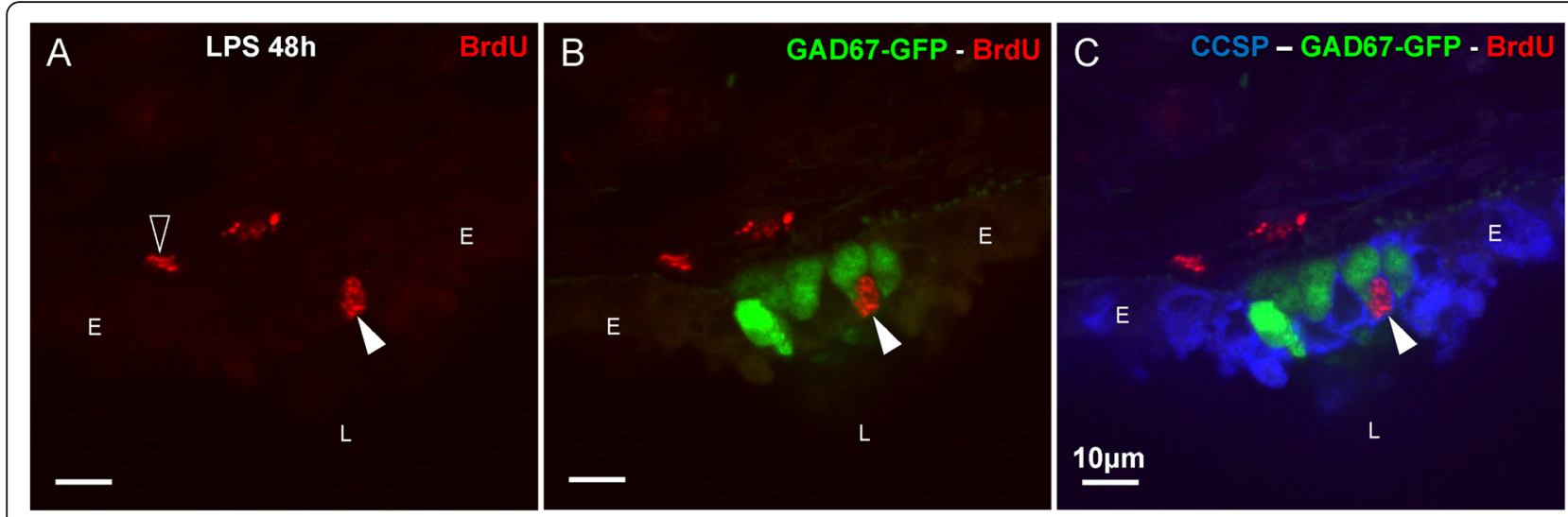

Fig. 7 Single confocal optical section of the airway epithelium in a cryosection of the lungs of a GAD67-GFP mouse $48 \mathrm{~h}$ after challenge with LPS. a BrdU-positive nucleus (arrowhead; red Cy3 fluorescence) in the airway epithelium, and some subepithelial BrdU staining (open arrowhead). b Combination with GAD67-GFP fluorescence (green), marking PNECs in the NEB ME. c Image of the three channels. In the same section, CCs/ CLCS are immunostained for the Clara cell-specific protein CCSP (blue pseudo-color of Cy5 fluorescence), and are seen to surround GFP-labeled NEB cells. Note that the divided epithelial cell (BrdU-labeled nucleus; arrowhead) is located adjacent to the PNECs and co-stained with CCSP, and can therefore be identified as a CLC. L: airway lumen, E: airway epithelium

eight BrdU-stained cells and $10 \%$ of the NEBs even nine or more (mean number: $3.55 \pm 0.6$ BrdU-positive cells/ NEB ME; total of 256.3 BrdU-positive cells/100 NEBs).

Overall (Fig. 10 and Table 3), quantitative analysis revealed that the NEB MEs in untreated controls typically display a very low number of BrdU-positive airway epithelial cells, indicating that virtually no cells have divided

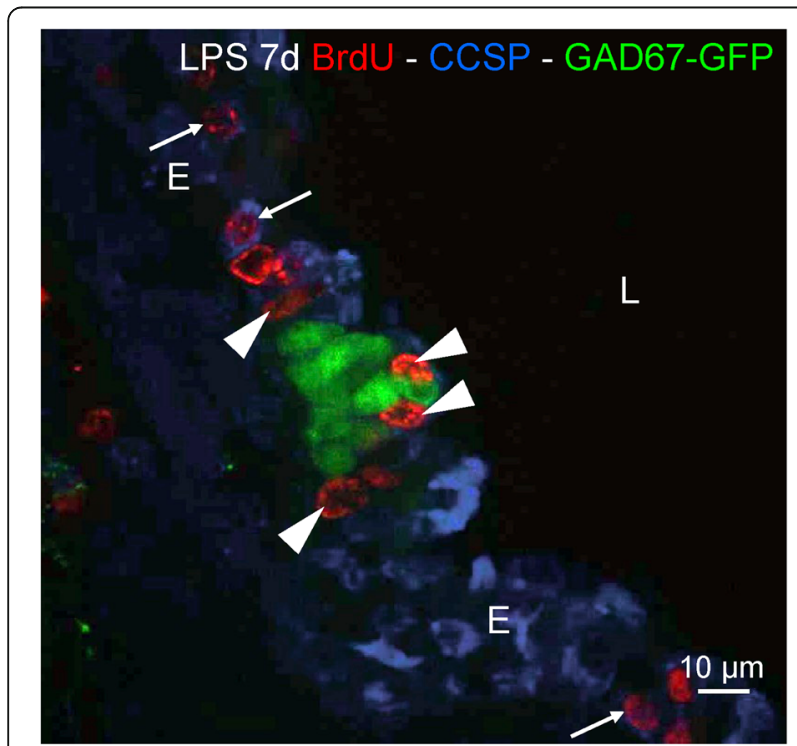

Fig. 8 Distribution of divided (BrdU-stained; red Cy3 fluorescence) airway epithelial cells seven days after LPS challenge. Similar to the $48 \mathrm{~h}$ time window, several CCSP-immunostained (blue pseudo-color of Cy5 fluorescence), BrdU-positive nuclei (arrowheads) can be observed specifically surrounding GAD67-GFP fluorescent (green) PNECS in the NEB ME. Note, however, the additional presence of CCSP-stained BrdU-labeled CCS in the surrounding airway epithelium (open arrowheads). L: airway lumen, E: airway epithelium during the $48 \mathrm{~h}$ experimental window. The manipulation of intratracheal instillation $(0.9 \% \mathrm{NaCl}$; sham-control) on its own appeared to induce a limited but enhanced cell division in the NEB ME, whereas the percentage of NEBs with BrdU-stained cells in the NEB ME and the total number of divided cells were remarkably higher after LPS instillation.

\section{Subdivision of BrdU-labeled cell types in the NEB ME}

For a limited number of experiments $(n=3$ GAD67GFP mice per group), all BrdU-labeled cells of each NEB ME were individually identifiec- as CLCs or PNECs- and counted (data shown in Fig. 11). Clearly, the number of divided PNECs was very limited compared to that of CLCs in the NEB ME. Moreover, the mean number of BrdU-labeled PNECs was not significantly different between the three experimental groups (Kruskal-Wallis; $p=0.25$ ).

These additional data further confirmed the significantly higher number of divided CLCs in the LPStreated group (Kruskal-Wallis; $p=0.01$ ).

\section{Discussion}

Despite having a very low cellular turnover rate in healthy conditions, the lung and airway epithelium are capable of responding quickly to acute injury, due to the presence of a restricted set of quiescent stem cells that are able to re-enter the cell cycle [4]. Detailed knowledge of the molecular characteristics, silencing and activation pathways of these specific types of stem cells will be essential for a good understanding of the possibilities for lung regeneration after injury. It is, however, very challenging to study rare cell populations with potential but 'dormant' stem cell characteristics in healthy lungs. 


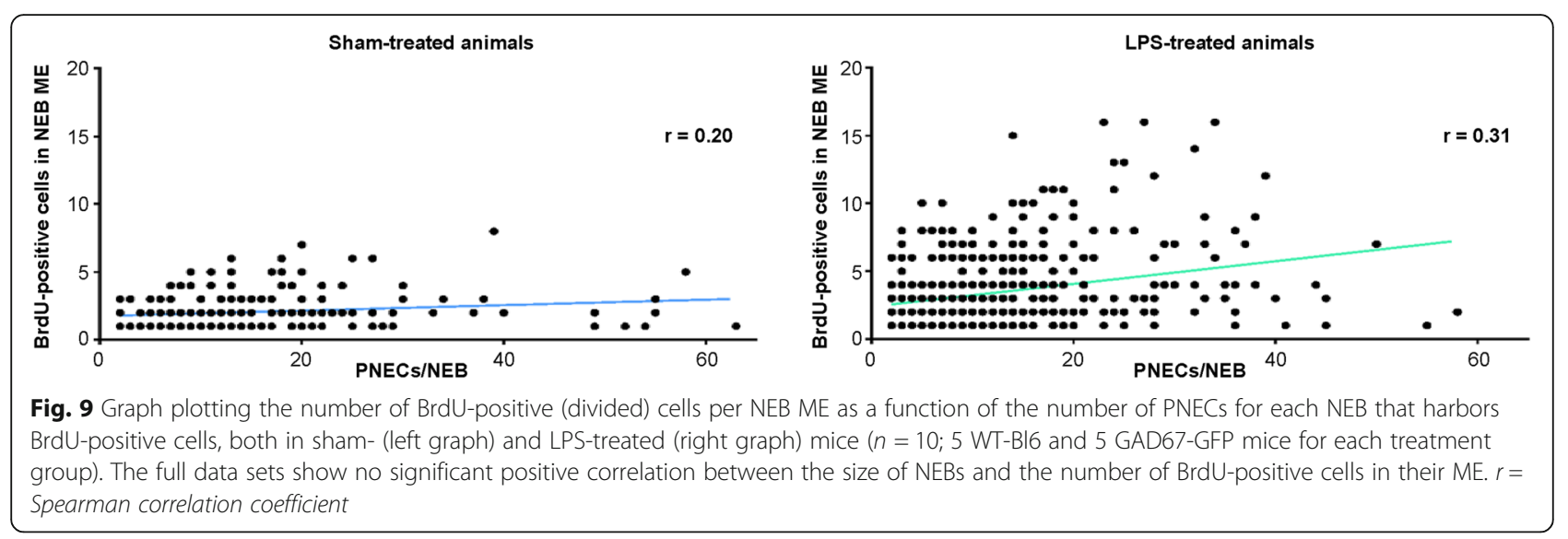

Subject of the present study are poorly studied potential airway stem cells that are selectively located in the pulmonary NEB ME. We developed a highly reproducible and minimally invasive model for transient lung inflammation, based on a single low-dose intratracheal LPS instillation.

The bacterial endotoxin LPS is commonly used to induce a pulmonary inflammatory response because it is easy to administer and it tends to result in a reproducible lung injury (for review see [57]). According to literature data, intratracheal instillation with doses of
$0.2 \mathrm{mg} \mathrm{LPS} / \mathrm{kg} \mathrm{BW}$ or less may be regarded as physiological [52], whereas $5 \mathrm{mg} \mathrm{LPS} / \mathrm{kg}$ BW results in a moderate reversible lung injury $[62,63]$, which prompted us to apply $1 \mathrm{mg} \mathrm{LPS} / \mathrm{kg} \mathrm{BW}$ in the presented model.

Unrestrained whole-body plethysmography revealed that respiratory functions -selected parameters were Te, RT, EIP and TV- were compromised during the first two to six hours following a single low-dose LPS challenge, but also that these physiological parameters returned to the level of untreated control mice within $8 \mathrm{~h}$ after treatment.

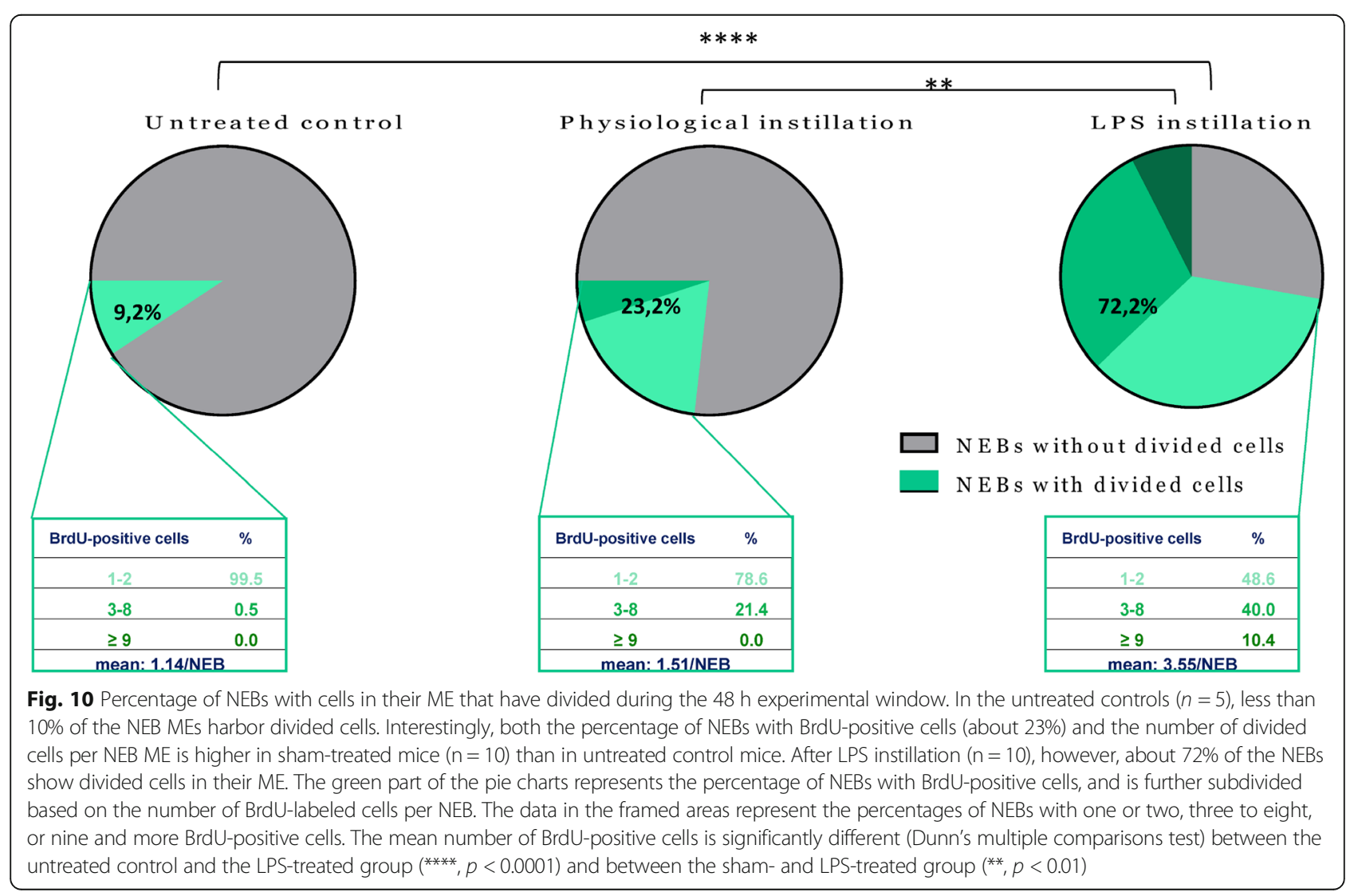


Table 3 Representation of the total number of BrdU-positive cells in the NEB ME

\begin{tabular}{|c|c|c|c|c|c|c|}
\hline \multicolumn{7}{|l|}{ Untreated control } \\
\hline Total number of BrdU $U^{+}$cells & 11 & 8 & 11 & & 9 & 0 \\
\hline NEB ME with $\leq 2$ BrdU $^{+}$cells & 6 & 6 & 6 & & 7 & 0 \\
\hline$\geq 2 \mathrm{BrdU}^{+}$cells $\geq 9 \mathrm{BrdU}^{+}$cells & 10 & 10 & 0 & 0 & 00 & 0 \\
\hline \multicolumn{7}{|l|}{ Sham-treated } \\
\hline Total number of $B r d U^{+}$cells & 16 & 61 & 54 & & 21 & 15 \\
\hline NEB ME with $\leq 2$ BrdU $^{+}$cells & 10 & 21 & 25 & & 10 & 9 \\
\hline$\geq 2 \mathrm{BrdU}^{+}$cells $\geq 9 \mathrm{BrdU}^{+}$cells & 00 & 90 & 4 & 0 & 10 & 0 \\
\hline \multicolumn{7}{|l|}{ LPS-treated } \\
\hline Total number of BrdU $U^{+}$cells & 187 & 316 & 135 & & 130 & 190 \\
\hline NEB ME with $\leq 2$ BrdU $^{+}$cells & 13 & 33 & 32 & & 30 & 49 \\
\hline$\geq 2 \mathrm{BrdU}^{+}$cells $\geq 9 \mathrm{BrdU}^{+}$cells & $4 \quad 20$ & 366 & $6 \quad 21$ & 0 & 92 & 20 \\
\hline
\end{tabular}

Cytospin preparations of BALF, collected $16 \mathrm{~h}$ after LPS treatment, showed many neutrophils, indicative of an inflammatory reaction. This observation is in line with literature data showing that intratracheal LPS exposure resulted in a pulmonary infiltration of neutrophils as early as $4 \mathrm{~h}$ after challenge [51]. At the time point of evaluation of cell division, i.e., $48 \mathrm{~h}$ after LPS instillation, the morphology of the airway epithelium could not be distinguished from that in untreated control mice, as shown in H\&E-stained lung cryostat sections.

It can be concluded that the intratracheal LPS challenge used in the present study does initiate an early influx of neutrophils, reminiscent of airway inflammation, but that the resulting injury is very mild and transient. The latter aspect is in contrast to the severe lung injury models that so far have been used in the majority of studies dealing with the activation of dedicated airway epithelial stem cell niches [44, 57], and will be discussed further on.
Cell-free BALF has been reported to harbor elevated cyto- and chemokine levels in the early phase (4 h$24 \mathrm{~h}$ hours) after intratracheal LPS instillation [52]. In the later phase (24-48 h post-instillation) these cytokine concentrations normalize, although the number of neutrophils remains elevated for at least $72 \mathrm{~h}$ [52].

To evaluate the potential effects of soluble mediators in BALF on healthy mouse airway epithelium, we collected BALF of LPS-challenged mice $16 \mathrm{~h}$ post-instillation. Acute short-term application of this BALF to the airway epithelium, and in particular to the NEB ME, in ex vivo lung slices of control mice in the course of LCI experiments, revealed a reversible and reproducible selective calcium-mediated activation of CLCs, but not of NEB cells, CCs or ciliated cells. Since administration of BALF of control mice (sham-treated and untreated), or of an LPS-containing solution, in our settings failed to mimic the activation of CLCs, it is reasonable to assume that one of the soluble inflammatory mediators released by activated macrophages and/or infiltrated neutrophils in the BALF may trigger the observed calciummediated activation of CLCs. So far, the identity of the molecule that is responsible for activation of the CLCs remains unknown and needs further investigation, which was not the focus of the present study.

Logically assuming that the NEB MEs in LPSchallenged mice are continuously exposed to bronchoalveolar lining fluid that harbors the same mediators as BALF, the presented study was designed to find out what could be the effect on CLCs as a potential quiescent stem cell population.

Mainly during fetal and early postnatal life, stem cell characteristics have been ascribed to CLCs [12, 30, 6467]. Lineage-tracing models suggest that CLCs have the capacity to self-renew [12, 42]. Clara cell-like precursors appear to generate both Clara and ciliated cells during development and repair, driven by Notch signaling [45, 46], and have been suggested to contribute to homeostasis of the intrapulmonary airway epithelium [35, 42].

Full depletion of progenitor CCs and lineage tracing have resulted in the identification of a rare label-retaining

\begin{tabular}{|c|c|c|c|c|c|}
\hline \multicolumn{6}{|l|}{ A } \\
\hline & \multicolumn{2}{|l|}{ CLCs } & & \multicolumn{2}{|l|}{ PNECs } \\
\hline $\begin{array}{l}\text { LPS-treated+ BrdU } \\
\qquad(n=3)\end{array}$ & $3.38 \pm 0.47$ & $1 * 1$ & & $0.13 \pm 0.07$ & क] \\
\hline $\begin{array}{c}\text { sham-treated + BrdU } \\
\quad(n=3)\end{array}$ & $1.94 \pm 0.15$ & I & * & $0.15 \pm 0.05$ & $\bar{z}$ \\
\hline $\begin{array}{l}\text { untreated + BrdU } \\
\quad(n=3)\end{array}$ & $1.61 \pm 0.07$ & & & $0.03 \pm 0.02$ & \\
\hline
\end{tabular}

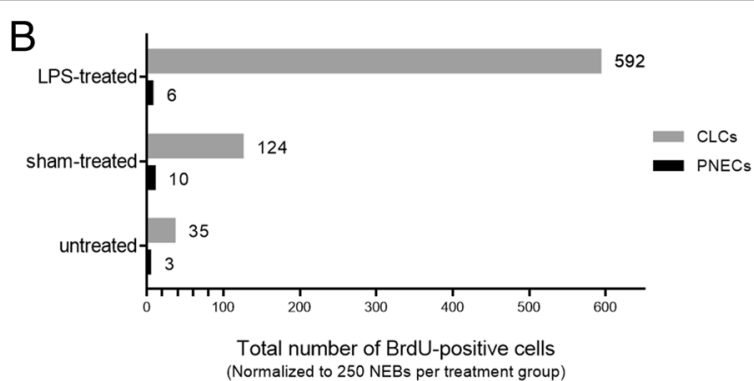

Fig. 11 Table providing the mean numbers of divided (BrdU-labeled) CLCs and PNECs per activated NEB ME (a) and graph representing the total numbers of BrdU-positive CLCs and PNECs (b) for all quantified NEBs in the three experimental groups ( $n=3$ GAD67-GFP mice per group) 
and self-renewing subpopulation of CCs in the NEB ME [68], referred to as CLCs in the present study, which behave as airway epithelial stem cells and/or are critical for stem cell maintenance [12]. Both regeneration and tumor formation may be directed by CCs or at least subpopulations of CCs with progenitor or stem cell characteristics [50, 69-71].

Until now, it has been believed that severe injury is required to activate dedicated airway epithelial stem cell niches - such as the NEB ME- for repair, while replacement of epithelial cells after mild injury (including homeostasis) is thought to be managed by the large pool of general CCs [2]. Interestingly, we show here that mild injury under the right conditions definitely can result in the selective activation of silent CLCs in the NEB ME and not of general CCs.

Our observation (both from LCI and cell proliferation studies) of the activation of dedicated airway epithelial stem cells, in the apparent absence of damage, suggests that early mediators of the induced inflammation may be directly involved in activating the stem cells. This idea is supported by recent publications pointing out the emerging role of neutrophils in repair after lung injury, highlighting the essential contribution of neutrophils which can transmigrate into the airspaces within minutes after the initial insult- in both early injury and repair (for review see [72]).

Incorporation of the thymidine analogue $\mathrm{BrdU}$ in DNA during the S-phase of cell division is a commonly used method to follow cell proliferation in a selected experimental time window [73, 74]. In the present study, BrdU incorporation for $48 \mathrm{~h}$ and subsequent BrdU immunostaining in cryostat sections, revealed that cell division was very rare in airway epithelium of untreated control mice, while a large number of BrdU-positive (divided) cells were present in the epithelium of small intestinal villi. These observations are in accordance with literature reports for rodents, with an estimated life time of about 4 days for enterocytes in the small intestine, whereas the turnover time of postnatal airway epithelium is more than 100 days [47]. Although some differences in proliferation of airway epithelial cells -probably due to health and pathogen status, strain and age of individual animals- have been reported (for review see [75]), cell division remains remarkably low in the absence of injury [4].

In our experimental setting, combined LPS challenge and BrdU incorporation resulted in a strongly enhanced proliferation of epithelial cells, the majority of which are typically grouped around NEB cells $48 \mathrm{~h}$ after LPS challenge. At that time point, the number of divided cells in the NEB ME was found to be 24.6 fold higher in LPS-treated mice than in untreated controls (256.3 vs. 10.4 BrdU-positive cells/100 NEBs), with some NEBs showing up to 24 divided cells in their ME niche. Quantification of the divided cells for each NEB ME and comparison between the LPS-treated and untreated control group showed that LPS challenge induced a highly significant proliferation of cells surrounding the NEBs, i.e., more than $72 \%$ of all counted NEBs harbored divided cells in their ME after $48 \mathrm{~h}$ as opposed to less than $10 \%$ in control mice. Double staining for CCSP, a marker for CCs and CLCs, as well as the location of the proliferated cell type were used to identify the majority of divided cells in the NEB ME as CLCs. The observation that CCSP-positive, BrdU-retaining CLCs were still found in the NEB ME 7 days after LPS challenge, in addition to the presence of CCSP-positive BrdU-labeled CCs dispersed in the airway epithelium surrounding NEBs, strongly implicates CLCs in the NEB ME as a population of self-renewing stem cells.

Although the adopted single low-dose intratracheal LPS challenge mouse model was shown to cause only mild and transient inflammation, it did induce a prominent selective proliferation of CLCs in the NEB ME.

No significant correlation was found between the size of NEBs (number of PNECs) and the number of BrdU-positive (divided) CLCs in the NEB ME following LPS challenge. The observed trend that larger NEBs harbored slightly more divided CLCs might simply be explained by the fact that the absolute number of CLCs is higher around large groups of PNECs.

In sham-treated mice (intratracheal instillation with saline), divided cells were also observed in an elevated percentage of NEBs (more than 23\%), compared to untreated animals (less than 10\%), but the total number of BrdU-positive cells was still limited compared to that observed following LPS challenge. Plethysmography showed that respiratory parameters did initially also change in sham-treated animals, but that they restored faster than in LPS-treated animals. Whereas BALF of untreated control mice harbored macrophages only, BALF of sham mice additionally contained neutrophils, but clearly less than BALF of LPS-instilled mice. Although the number of divided airway epithelial cells in sham-treated mice is small compared to that seen after LPS in our experiments, the preferential location of BrdU-labeled cells surrounding PNECs in the NEB ME is interestingly similar to the selective CLC proliferation seen after LPS treatment and suggestive of a joint mechanism of action, possibly involving early neutrophil mediators as discussed above.

Apart from CLCs (vCE cells), PNECs in the NEB ME have also been put forward as a cell type with potential airway epithelial stem cell characteristics [34, 35], although this hypothesis is still the subject of controversy.

The classic view that PNECs are terminally differentiated $[76,77]$, is challenged by the notion that repair of 
severe airway injury is associated with hyperplasia of PNECs [35]. Chemically or genetically induced full depletion of CCs revealed a typical proliferation of PNECs $[36,70]$. Although at least subpopulations of PNEC-like progenitors are believed to give rise to CCs and even to alveolar epithelial cells during early development [30, 78, 79], most studies suggest that PNECs are not able to restore adult airway epithelium after ablation of all types of CCs [12]. Elimination of PNECs prior to CC depletion seems to have no apparent consequence for $\mathrm{CC}$ regeneration [34], but the same study reports that to some extent PNECs may contribute to CCs and ciliated cells following severe lung injury.

The presented data (LPS treatment; $48 \mathrm{~h}$ experimental window) show a very low number of divided PNECs in the NEB ME, which is not significantly different between LPS-challenged, sham and untreated control mice. In contrast to the well-illustrated proliferation of endocrine cells (PNECs) in addition to CLCs/vCE cells in several studies that are based on a full depletion of CCs [12, 35, 70], our LPS-based transient mild injury model for the selective proliferation of CLCs offers the important advantage that PNECs in the NEB ME are not affected by the procedure. The latter is in agreement with our observation that soluble mediators in BALF of LPSchallenged mice result in a calcium-mediated activation of CLCs but not of PNECs in the NEB ME in lung slices of control mice.

Certainly, PNECs can secrete regulatory factors -e.g. gastrin-releasing peptide (bombesin) and CGRP, potential epithelial cell mitogens [80]- that may support and regulate airway epithelial cell renewal/proliferation and differentiation. PNECs, however, are not only able to produce, store and secrete a variety of bioactive substances -some of which may directly influence CLCs [13]- but also to monitor calcium-mediated events in surrounding CLCs [14], and may therefore be involved in creating a niche to maintain the stem cell characteristics of CLCs.

\section{Conclusion}

Based on a single low-dose intratracheal LPS instillation, a highly reproducible and minimally invasive lung inflammation model was generated and validated for inducing selective activation of a quiescent airway stem cell population -the so-called CLCs/vCE cells- in the NEB ME.

Important advantages compared to earlier models, which were mainly based on full ablation of CCs, are the absence of both severe epithelial injury and additional proliferation of endocrine cells (PNECs).

The fact that CLCs in the NEB ME can be activated from a silent to a dividing stem cell population in the absence of severe airway epithelial damage creates new opportunities for unraveling the cellular mechanisms/ pathways regulating silencing, activation, proliferation and differentiation of this unique postnatal airway epithelial stem cell population.

The presented data are supportive of potentially important selective roles of the postnatal airway stem cell niche of the NEB ME, and enable the identification of pathways that should allow uncoupling of essential repair mechanisms from severe lung injury and inflammation.

\begin{abstract}
Abbreviations
$\left[\mathrm{Ca}^{2+}\right]_{i}$ Intracellular calcium concentration; $\left[\mathrm{K}^{+}\right]_{0}$ : Extracellular potassium concentration; 4-Di-2-ASP: 4-(4-diethylaminostyryl)-N-methylpyridinium iodide; BALF: Bronchoalveolar lavage fluid; BrdU: 5-bromo-2'-deoxyuridine; BSA: Bovine serum albumin; BW: Bodyweight; CAE: Control airway epithelium; CC: Clara cell; CCSP: Clara cell secretory protein; CGRP: Calcitonin gene-related peptide; CLC: Clara-like cell; DMEM-F-12: Dulbecco's modified Eagle's medium/F-12; EIP: End-inspiratory pause; GAD67: Glutamic acid decarboxylase 67; H\&E: Hematoxylin and eosin; i.p.: Intraperitoneal; LCI: Live cell imaging; LMD: Laser microdissection; LPS: Lipopolysaccharide; Mc: Monoclonal; ME: Microenvironment; NEB ME: Neuroepithelial body microenvironment; NEB: Neuroepithelial body; PBS: Phosphate-buffered saline; PC: Polyclonal; PD: Postnatal day; PF: Paraformaldehyde;

PNEC: Pulmonary neuroendocrine cell; ROI: Region of interest; RT: Relaxation time; SCLC: Small cell lung carcinoma; SEM: Standard error of means; Te: Expiratory time; TV: Tidal volume; UP1: Urine protein 1; VCE: Variant CCSPexpressing; WT-Bl6: Wild type C57BL/6 J
\end{abstract}

\section{Acknowledgements}

The authors wish to thank Dominique De Rijck, Robrecht Lembrechts, Carmen Rottiers, Francis Terloo, Elien Theuns, Sofie Thys and Danny Vindevogel for their assistance.

\section{Funding}

This study was financially supported by a GOA BOF 2015 grant (No. 30729) of the University of Antwerp.

\section{Availability of data and materials}

The datasets used and/or analyzed during the current study are available from the corresponding author on reasonable request.

\section{Authors' contributions}

LV developed and carried out the experiments and prepared the manuscript. DA and IB designed the experiments, supervised the analysis and edited the manuscript. All authors regularly discussed the experiments and data, commented on the text, and read and approved the submitted manuscript.

\section{Ethics approval}

National and international principles of laboratory animal care were followed, and experiments were approved by the local animal ethics committee of the University of Antwerp (ECD 2014-66 and 2017-49).

\section{Consent for publication}

Not applicable.

\section{Competing interests}

The authors declare that they have no competing interests.

\section{Publisher's Note}

Springer Nature remains neutral with regard to jurisdictional claims in published maps and institutional affiliations.

Received: 6 July 2018 Accepted: 17 October 2018

Published online: 26 October 2018

\section{References}

1. Thurlbeck WM. Postnatal growth and development of the lung. Am Rev Respir Dis. 1975;111:803-44. 
2. Giangreco A, Arwert EN, Rosewell IR, Snyder J, Watt FM, Stripp BR. Stem cells are dispensable for lung homeostasis but restore airways after injury. Proc Natl Acad Sci U S A. 2009;106:9286-91.

3. Bertoncello I, McQualter JL. Lung stem cells: do they exist? Respirology. 2013;18:587-95

4. Stabler CT, Morrisey EE. Developmental pathways in lung regeneration. Cell Tissue Res. 2017;367:677-85.

5. Bishop AE. Pulmonary epithelial stem cells. Cell Prolif. 2004;37:89-96.

6. Rock JR, Hogan BL. Epithelial progenitor cells in lung development, maintenance, repair, and disease. Annu Rev Cell Dev Biol. 2011;27:493-512.

7. Adriaensen D, Scheuermann DW. Neuroendocrine cells and nerves of the lung. Anat Rec. 1993;236:70-86

8. De Proost I, Pintelon I, Brouns I, Kroese AB, Riccardi D, Kemp PJ, Timmermans JP, Adriaensen D. Functional live cell imaging of the pulmonary neuroepithelial body microenvironment. Am J Respir Cell Mol Biol. 2008;39:180-9.

9. Brouns I, Pintelon I, Timmermans JP, Adriaensen D. Novel insights in the neurochemistry and function of pulmonary sensory receptors. Adv Anat Embryol Cell Biol. 2012;211:1-115.

10. Haller CJ. A scanning and transmission electron-microscopic study of the development of the surface-structure of neuroepithelial bodies in the mouse lung. Micron. 1994;25:527-38.

11. Stahlman MT, Gray ME. Ontogeny of neuroendocrine cells in human-fetal lung 1. An electron-microscopic study. Lab Investig. 1984;51:449-63.

12. Hong KU, Reynolds SD, Giangreco A, Hurley CM, Stripp BR. Clara cell secretory protein-expressing cells of the airway neuroepithelial body microenvironment include a label-retaining subset and are critical for epithelial renewal after progenitor cell depletion. Am J Respir Cell Mol Biol. 2001;24:671-81.

13. De Proost I, Pintelon I, Wilkinson WJ, Goethals S, Brouns I, Van Nassauw L, Riccardi D, Timmermans JP, Kemp PJ, Adriaensen D. Purinergic signaling in the pulmonary neuroepithelial body microenvironment unraveled by live cell imaging. FASEB J. 2009;23:1153-60.

14. Lembrechts R, Brouns I, Schnorbusch K, Pintelon I, Kemp PJ, Timmermans JP, Riccardi D, Adriaensen D. Functional expression of the multimodal extracellular calcium-sensing receptor in pulmonary neuroendocrine cells. J Cell Sci. 2013;126:4490-501.

15. Lembrechts R, Brouns I, Schnorbusch K, Pintelon I, Timmermans JP, Adriaensen D. Neuroepithelial bodies as mechanotransducers in the intrapulmonary airway epithelium: involvement of TRPC5. Am J Respir Cell Mol Biol. 2012:47:315-23.

16. Pan J, Yeger $\mathrm{H}$, Cutz E. Innervation of pulmonary neuroendocrine cells and neuroepithelial bodies in developing rabbit lung. J Histochem Cytochem. 2004:52:379-89.

17. Cutz E, Chan W, Track NS. Bombesin, calcitonin and leu-enkephalin immunoreactivity in endocrine cells of human lung. Experientia. 1981;37:765-7.

18. Gallego R, Garcia-Caballero T, Roson E, Beiras A. Neuroendocrine cells of the human lung express substance-P-like immunoreactivity. Acta Anat (Basel). 1990;139:278-82.

19. Brouns I, Oztay F, Pintelon I, De Proost I, Lembrechts R, Timmermans JP, Adriaensen D. Neurochemical pattern of the complex innervation of neuroepithelial bodies in mouse lungs. Histochem Cell Biol. 2009;131:55-74.

20. Pan J, Copland I, Post M, Yeger H, Cutz E. Mechanical stretch-induced serotonin release from pulmonary neuroendocrine cells: implications for lung development. Am J Physiol Lung Cell Mol Physiol. 2006;290:L185-93.

21. Adriaensen D, Brouns I, Van Genechten J, Timmermans JP. Functional morphology of pulmonary neuroepithelial bodies: extremely complex airway receptors. Anat Rec. 2003;270:25-40.

22. Linnoila RI. Functional facets of the pulmonary neuroendocrine system. Lab Investig. 2006;86:425-44

23. Cutz E, Jackson A. Neuroepithelial bodies as airway oxygen sensors. Respir Physiol. 1999;115:201-14.

24. Cutz E, Yeger H, Pan J, Ito T. Pulmonary neuroendocrine cell system in health and disease. Curr Respir Med Rev. 2008:4:174-86.

25. Sorokin SP, Hoyt RF. On the supposed function of neuroepithelial bodies in adult mammalian lungs. News Physiol Sci. 1990;5:89-95.

26. Sorokin SP, Hoyt RF Jr, Shaffer MJ. Ontogeny of neuroepithelial bodies: correlations with mitogenesis and innervation. Microsc Res Tech. 1997;37:43-61

27. Van Lommel A. Pulmonary neuroendocrine cells (PNEC) and neuroepithelial bodies (NEB): chemoreceptors and regulators of lung development. Paediatr Respir Rev. 2001;2:171-6.
28. Hoyt RF, Sorokin SP, Mcdowell EM, Mcnelly NA. Neuroepithelial bodies and growth of the airway epithelium in developing hamster lung. Anat Rec. 1993;236:15-24

29. Li F, He J, Wei J, Cho WC, Liu X. Diversity of epithelial stem cell types in adult lung. Stem Cells Int. 2015;2015:728307.

30. Guha A, Vasconcelos M, Cai Y, Yoneda M, Hinds A, Qian J, Li G, Dickel L, Johnson JE, Kimura $\mathrm{S}$, et al. Neuroepithelial body microenvironment is a niche for a distinct subset of Clara-like precursors in the developing airways. Proc Natl Acad Sci U S A. 2012;109:12592-7.

31. Rawlins EL, Okubo T, Que J, Xue Y, Clark C, Luo X, Hogan BL. Epithelial stem/progenitor cells in lung postnatal growth, maintenance and repair. Cold Spring Harb Symp Quant Biol. 2008;73:291-5.

32. Asselin-Labat ML, Filby CE. Adult lung stem cells and their contribution to lung tumourigenesis. Open Biol. 2012;2:120094.

33. Verckist L, Lembrechts $R$, Thys S, Pintelon I, Timmermans JP, Brouns I, Adriaensen D. Selective gene expression analysis of the neuroepithelial body microenvironment in postnatal lungs with special interest for potential stem cell characteristics. Respir Res. 2017;18:87.

34. Song H, Yao E, Lin C, Gacayan R, Chen MH, Chuang PT. Functiona characterization of pulmonary neuroendocrine cells in lung development, injury, and tumorigenesis. Proc Natl Acad Sci U S A. 2012;109:17531-6.

35. Reynolds SD, Giangreco A, Power JHT, Stripp BR. Neuroepithelial bodies of pulmonary airways serve as a reservoir of progenitor cells capable of epithelial regeneration. Am J Pathol. 2000;156:269-78.

36. Peake JL, Reynolds SD, Stripp BR, Stephens KE, Pinkerton KE. Alteration of pulmonary neuroendocrine cells during epithelial repair of naphthaleneinduced airway injury. Am J Pathol. 2000;156:279-86.

37. Giangreco A, Reynolds SD, Stripp BR. Terminal bronchioles harbor a unique airway stem cell population that localizes to the bronchoalveolar duct junction. Am J Pathol. 2002;161:173-82.

38. Davies SJ, Gosney JR, Hansell DM, Wells AU, du Bois RM, Burke MM, Sheppard MN, Nicholson AG. Diffuse idiopathic pulmonary neuroendocrine cell hyperplasia: an under-recognised spectrum of disease. Thorax. 2007;62:248-52.

39. Pan J, Yeger H, Ratcliffe P, Bishop T, Cutz E. Hyperplasia of pulmonary neuroepithelial bodies (NEB) in lungs of prolyl hydroxylase -1(PHD-1) deficient mice. Adv Exp Med Biol. 2012;758:149-55.

40. Naizhen X, Linnoila RI, Kimura S. Co-expression of Achaete-Scute Homologue-1 and calcitonin gene-related peptide during NNK-induced pulmonary neuroendocrine hyperplasia and carcinogenesis in hamsters. J Cancer. 2016;7:2124-31.

41. Sutherland KD, Proost N, Brouns I, Adriaensen D, Song JY, Berns A. Cell of origin of small cell lung cancer: inactivation of Trp53 and Rb1 in distinct cell types of adult mouse lung. Cancer Cell. 2011;19:754-64.

42. Rawlins EL, Okubo T, Xue Y, Brass DM, Auten RL, Hasegawa H, Wang F, Hogan BL. The role of Scgbla1 ${ }^{+}$Clara cells in the long-term maintenance and repair of lung airway, but not alveolar, epithelium. Cell Stem Cell. 2009; 4:525-34.

43. Guha A, Deshpande A, Jain A, Sebastiani P, Cardoso WV. Uroplakin 3a+ cells are a distinctive population of epithelial progenitors that contribute to airway maintenance and post-injury repair. Cell Rep. 2017;19:246-54.

44. Vaughan $\mathrm{AE}$, Chapman HA. Regenerative activity of the lung after epithelial injury. Biochim Biophys Acta. 2013;1832:922-30.

45. Xing Y, Li A, Borok Z, Li C, Minoo P. NOTCH1 is required for regeneration of Clara cells during repair of airway injury. Stem Cells. 2012;30:946-55.

46. Collins BJ, Kleeberger W, Ball DW. Notch in lung development and lung cancer. Semin Cancer Biol. 2004;14:357-64.

47. Blenkinsopp WK. Proliferation of respiratory tract epithelium in the rat. Exp Cell Res. 1967:46:144-54

48. Wansleeben C, Barkauskas CE, Rock JR, Hogan BL. Stem cells of the adult lung: their development and role in homeostasis, regeneration, and disease. Wiley Interdiscip Rev Dev Biol. 2013;2:131-48.

49. Lynch TJ, Engelhardt JF. Progenitor cells in proximal airway epithelial development and regeneration. Cell Biochem. 2014;115:1637-45.

50. Stripp BR, Maxson K, Mera R, Singh G. Plasticity of airway cell proliferation and gene expression after acute naphthalene injury. Am J Phys. 1995;269: L791-9.

51. Starcher B, Williams I. A method for intratracheal instillation of endotoxin into the lungs of mice. Lab Anim. 1989:23:234-40.

52. Vernooy JHJD, Dentener MA, van Suylen RJ, Buurman WA, Wouters EFM. Intratracheal instillation of lipopolysaccharide in mice induces apoptosis in bronchial epithelial cells. Am J Respir Cell Mol Biol. 2001;24:569-76. 
53. Zhang Y, Xu T, Pan Z, Ge X, Sun C, Lu C, Chen H, Xiao Z, Zhang B, Dai Y, Liang G. Shikonin inhibits myeloid differentiation protein 2 to prevent LPS induced acute lung injury. Br J Pharmacol. 2018;175:840-54.

54. Nelson AJ, Roy SK, Warren K, Janike K, Thiele GM, Mikuls TR, Romberger DJ, Wang D, Swanson B, Poole JA. Sex differences impact the lung-bone inflammatory response to repetitive inhalant lipopolysaccharide exposures in mice. J Immunotoxicol. 2018;15:73-81.

55. Fodor RS, Georgescu AM, Cioc AD, Grigorescu BL, Cotoi OS, Fodor $P$ Copotoiu SM, Azamfirei L. Time- and dose-dependent severity of lung injury in a rat model of sepsis. Romanian J Morphol Embryol. 2015;56:1329-37.

56. Alm AS, Li K, Chen H, Wang D, Andersson R, Wang X. Variation of lipopolysaccharide-induced acute lung injury in eight strains of mice. Respir Physiol Neurobiol. 2010;171:157-64

57. Matute-Bello G, Frevert CW, Martin TR. Animal models of acute lung injury. Am J Physiol Lung Cell Mol Physiol. 2008;295:L379-99.

58. Schnorbusch K, Lembrechts R, Pintelon I, Timmermans JP, Brouns I, Adriaensen D. GABAergic signaling in the pulmonary neuroepithelial body microenvironment: functional imaging in GAD67-GFP mice. Histochem Cell Biol. 2013;140:549-66.

59. Stapleton CM, Jaradat M, Dixon D, Kang HS, Kim SC, Liao G, Carey MA, Cristiano J, Moorman MP, Jetten AM. Enhanced susceptibility of staggerer (RORalphasg/sg) mice to lipopolysaccharide-induced lung inflammation. Am J Physiol Lung Cell Mol Physiol. 2005;289:L144-52.

60. Pintelon I, De Proost I, Brouns I, Van Herck H, Van Genechten J, Van Meir F, Timmermans JP, Adriaensen D. Selective visualisation of neuroepithelial bodies in vibratome slices of living lung by 4-Di-2-ASP in various animal species. Cell Tissue Res. 2005;321:21-33.

61. Matute-Bello G, Downey G, Moore BB, Groshong SD, Matthay MA, Slutsky AS, Kuebler WM. Acute lung injury in animals study G: an official American Thoracic Society workshop report: features and measurements of experimental acute lung injury in animals. Am J Respir Cell Mol Biol. 2011;44:725-38.

62. Chang YW, Tseng CP, Lee CH, Hwang TL, Chen YL, Su MT, Chong KY, Lan YW Wu CC, Chen KJ, et al. Beta-Nitrostyrene derivatives attenuate LPS-mediated acute lung injury via the inhibition of neutrophil-platelet interactions and NET release. Am J Physiol Lung Cell Mol Physiol. 2018;314:L654-69.

63. Jiang Z, Chen Z, Li L, Zhou W, Zhu L. Lack of SOCS3 increases LPS-induced murine acute lung injury through modulation of $L y 6 C(+)$ macrophages. Respir Res. 2017;18:217

64. Snyder JC, Teisanu RM, Stripp BR. Endogenous lung stem cells and contribution to disease. J Pathol. 2009;217:254-64

65. Roomans GM. Tissue engineering and the use of stem/progenitor cells for airway epithelium repair. Eur Cell Mater. 2010;19:284-99.

66. Kratz JR, Yagui-Beltran A, Jablons DM. Cancer stem cells in lung tumorigenesis. Ann Thorac Surg. 2010;89:S2090-5.

67. Sullivan JP, Minna JD, Shay JW. Evidence for self-renewing lung cancer stem cells and their implications in tumor initiation, progression, and targeted therapy. Cancer Metastasis Rev. 2010;29:61-72.

68. Reynolds SD, Malkinson AM. Clara cell: progenitor for the bronchiolar epithelium. Int J Biochem Cell Biol. 2010;42:1-4.

69. Plopper CG, Suverkropp C, Morin D, Nishio S, Buckpitt A. Relationship of cytochrome-P-450 activity to Clara cell cytotoxicity. 1. Histopathologic comparison of the respiratory-tract of mice, rats and hamsters after parenteral administration of naphthalene. J Pharmacol Exp Ther. 1992;261:353-63.

70. Reynolds SD, Hong KU, Giangreco A, Mango GW, Guron C, Morimoto Y, Stripp BR. Conditional Clara cell ablation reveals a self-renewing progenitor function of pulmonary neuroendocrine cells. Am J Physiol Lung Cell Mol Physiol. 2000;278:1256-63.

71. Crosby LM, Waters CM. Epithelial repair mechanisms in the lung. Am J Physiol Lung Cell Mol Physiol. 2010;298:L715-31.

72. Blazquez-Prieto J, Lopez-Alonso I, Huidobro C, Albaiceta GM. The emerging role of neutrophils in repair after acute lung injury. Am J Respir Cell Mol Biol. 2018;59:289-94

73. Taupin P. BrdU immunohistochemistry for studying adult neurogenesis: paradigms, pitfalls, limitations, and validation. Brain Res Rev. 2007:53:198-214.

74. Kameyama H, Kudoh S, Udaka N, Kagayama M, Hassan W, Hasegawa K, Niimori-Kita K, Ito T. BrdU label retaining cells in mouse terminal bronchioles. Histol Histopathol. 2014;29:659-68.

75. Rawlins EL, Hogan BL. Epithelial stem cells of the lung: privileged few or opportunities for many? Development. 2006;133:2455-65.

76. Gosney JR. Pulmonary neuroendocrine cell system in pediatric and adult lung disease. Microsc Res Tech. 1997;37:107-13.
77. Hoyt RF Jr, McNelly NA, Sorokin SP. Dynamics of neuroepithelial body (NEB) formation in developing hamster lung: light microscopic autoradiography after 3H-thymidine labeling in vivo. Anat Rec. 1990;227:340-50.

78. Li Y, Linnoila RI. Multidirectional differentiation of Achaete-Scute homologue-1-defined progenitors in lung development and injury repair. Am J Respir Cell Mol Biol. 2012;47:768-75.

79. Khoor A, Gray ME, Singh G, Stahlman MT. Ontogeny of Clara cell-specific protein and its mRNA: their association with neuroepithelial bodies in human fetal lung and in bronchopulmonary dysplasia. J Histochem Cytochem. 1996:44:1429-38.

80. Cutz E, Yeger H, Pan J. Pulmonary neuroendocrine cell system in pediatric lung disease-recent advances. Pediatr Dev Pathol. 2007;10:419-35.
Ready to submit your research? Choose BMC and benefit from:

- fast, convenient online submission

- thorough peer review by experienced researchers in your field

- rapid publication on acceptance

- support for research data, including large and complex data types

- gold Open Access which fosters wider collaboration and increased citations

- maximum visibility for your research: over $100 \mathrm{M}$ website views per year

At BMC, research is always in progress.

Learn more biomedcentral.com/submissions 